\title{
Stable Isotopic Evidence in Support of Active Microbial Methane Cycling in Low-Temperature Diffuse Flow Vents at 950'N East Pacific Rise
}

\author{
ACCEPTED- w/revised References \\ Giora Proskurowski ${ }^{\mathrm{a},{ }^{*}}$, Marvin D. Lilley ${ }^{\mathrm{a}}$, E.J. Olson ${ }^{\mathrm{a}}$ \\ ${ }^{\text {a }}$ School of Oceanography, University of Washington, Seattle, WA 98195 \\ *Corresponding author. \\ E-mail Address: giora@whoi.edu (G. Proskurowski)
}

Current address: Woods Hole Oceanographic Institution, MS\#4, Woods Hole, MA 02543

Running header: ${ }^{13} \mathrm{C}$ Evidence for Microbial Methane Cycling in $9^{\circ} \mathrm{N}$ EPR Diffuse Fluids

Index terms: methane, carbon dioxide, diffuse fluid, hydrothermal vents, methanogenesis, methane oxidation 


\begin{abstract}
A unique dataset from paired low- and high-temperature vents at 950’ $\mathrm{N}$ East Pacific Rise provides insight into the microbiological activity in low-temperature diffuse fluids. The stable carbon isotopic composition of $\mathrm{CH}_{4}$ and $\mathrm{CO}_{2}$ in $9^{\circ} 50^{\prime} \mathrm{N}$ hydrothermal fluids indicates microbial methane production, perhaps coupled with microbial methane consumption. Diffuse fluids are depleted in ${ }^{13} \mathrm{C}$ by $\sim 10 \%$ in values of $\delta^{13} \mathrm{C}_{\text {of }} \mathrm{CH}_{4}$, and by $\sim 0.55 \%$ in values of $\delta^{13} \mathrm{C}$ of $\mathrm{CO}_{2}$, relative to the values of the high-temperature source fluid $\left(\delta^{13} \mathrm{C}_{\text {of }} \mathrm{CH}_{4}=-20.1 \pm 1.2 \%\right.$, $\delta^{13} \mathrm{C}$ of $\mathrm{CO}_{2}=-4.08 \pm 0.15 \%$ ). Mixing of seawater or thermogenic sources cannot account for the depletions in ${ }^{13} \mathrm{C}$ of both $\mathrm{CH}_{4}$ and $\mathrm{CO}_{2}$ at diffuse vents relative to adjacent high-temperature vents. The substrate utilization and ${ }^{13} \mathrm{C}$ fractionation associated with the microbiological processes of methanogenesis and methane oxidation can explain observed steady-state $\mathrm{CH}_{4}$ and $\mathrm{CO}_{2}$ concentrations and carbon isotopic compositions. A mass-isotope numerical box-model of these paired vent systems is consistent with the hypothesis that microbial methane cycling is active at diffuse vents at $9^{\circ} 50^{\prime} \mathrm{N}$. The detectable ${ }^{13} \mathrm{C}$ modification of fluid geochemistry by microbial metabolisms may provide a useful tool for detecting active methanogenesis.
\end{abstract}




\section{INTRODUCTION}

Although the genetic traces of suites of archaea and bacteria have been identified in hydrothermal fluids at more than $300^{\circ} \mathrm{C}$ (DEMING and BARoss, 1993; HUBER et al., 2003; TAKAI and HoriKosHI, 1999), it is unlikely that these organisms were active well above the $\sim 120^{\circ} \mathrm{C}$ current upper temperature limit for life (KASHEFI and LOVLEY, 2003). While fluids at black smoker temperatures cannot be absolutely discounted as a potential microbial habitat (BAROsS et al., 2004; SCHRENK et al., 2003), it is much more plausible that these unique organisms were active in nearby lower temperature hydrothermal environments and entrained into the hot sampled fluid. Such lower temperature hydrothermal environments occur when hightemperature hydrothermal fluid is cooled, conductively or through mixing with seawater. The seafloor expressions of this low-temperature hydrothermal activity are diffusely venting fluids that provide a warm, mineral, metal, and volatile rich habitat that is amenable to microbial life.

The term "diffuse fluid", used interchangeably herein with "low-temperature fluid", explicitly refers to fluid venting directly out of cracks in the basaltic substrate (VON DAMM and LiLLEY, 2004). This definition of diffuse fluid does not include fluids leaking out of vent structures or shimmering water that is a result of high-temperature fluids mixing above the seafloor. Diffuse fluids have been shown to be, primarily, a dilution of high-temperature fluids and crustal seawater (ButTERFIELD et al., 1999; ButTERFIELD and MASSOTH, 1994). Conductive cooling of high-temperature fluids in the shallow crust (COOPER et al., 2000), and threecomponent mixing between high-temperature fluids, seawater, and modified-seawater sources (RAVIZZA et al., 2001), are minor formation mechanisms of diffuse fluids. 
The comparison of heat and chemical flux estimates from low-temperature and hightemperature fluids suggests a greater (BAKER et al., 1993; ELDERFIELD and SCHULTZ, 1996; SCHULTZ and ELDERFIELD, 1999) contribution to the global ocean basins from diffuse vents than from high-temperature vents. Despite the relative importance of diffuse fluids in hydrothermal systems, chemical data describing these low-temperature fluids have been sparsely reported, and the results have often been overshadowed by high-temperature revelations (BUTTERFIELD et al., 1999; ButTERFIELD and MASSOTH, 1994). Although the groundwork for detailed biological and chemical work in diffuse fluids was laid in a comprehensive study in the late 1980's (JOHNSON et al., 1988), not until recently have diffuse fluids emerged as the focal point of hydrothermal investigations (BUTTERFIELD et al., 2004; COOPER et al., 2000; HOLDEN et al., 1998; HuBER et al., 2003; VON DAMM and LiLLEY, 2004). Microbiological and geochemical interest in diffuse fluids has been invigorated in part because these fluids have been indicated as the closest environmental model for a subseafloor biosphere (SUMmiT and BAROSs, 2001). Despite the renewed focus, diffuse fluids remain challenging to study, both analytically and from a sampling standpoint.

As the name implies, diffuse fluids emanate from the seafloor in an unfocused wafting of warm water, unlike the focused flow of high-temperature fluids venting directly out of a chimney orifice. Thus, obtaining a sample of diffuse fluid without entraining large quantities of seawater is extremely rare, and diffuse samples are typically $90-95 \%$ seawater. The seawater dominated composition of diffuse fluids is problematic because large extrapolations (to a seawater-free endmember) are required to directly compare low-temperature and high-temperature fluid concentration data. A critical challenge in the evaluation of the microbiological impact on the chemistry of diffuse fluids is accurately assessing the modifications to the high-temperature 
parent fluid, a difficult task when using considerably manipulated concentration data. Because the effects of mixing and dilution are inherently recorded in isotopic data, the error and complexity in normalizing concentration data is muted or absent when comparing diffuse and high-temperature stable isotope data.

Many biological and chemical processes preferentially utilize ${ }^{12} \mathrm{C}$ relative to ${ }^{13} \mathrm{C}$, leaving substrates enriched in ${ }^{13} \mathrm{C}$ and metabolic products depleted in ${ }^{13} \mathrm{C}$. Thus, evidence for microbial metabolic activity may be preserved in the isotope record. We attribute the differences in the carbon isotopic composition of $\mathrm{CH}_{4}$ and $\mathrm{CO}_{2}$ between the low- and high-temperature fluids to microbiological modifications by methanogens and, perhaps, methanotrophs. As many biological and chemical processes preferentially utilize ${ }^{12} \mathrm{C}$ relative to ${ }^{13} \mathrm{C}$, microbial metabolisms typically yield substrates enriched in ${ }^{13} \mathrm{C}$ and metabolic products depleted in ${ }^{13} \mathrm{C}$. Methanogens, obligate anaerobic archaea that produce $\mathrm{CH}_{4}$ during the metabolism of an oxidized carbon source, are commonly detected and isolated from hydrothermal environments (JANNASCH, 1995). Methanotrophy, the microbial oxidation of methane, is mediated by methanotrophic bacteria in aerobic environments and by obligate anaerobic methanotrophic archaea in anaerobic environments. Although anaerobic methanotrophs have been identified in anoxic sediments (HINRICHS et al., 2000), indications that this group is active at hydrothermal vent environments is scarce, as anaerobic methane oxidizers have only been detected at the sedimented hydrothermal site Guaymas (TESKE et al., 2002).

To decipher the impact of microbial activity in hydrothermal fluids, links between specific microbial groups and specific geochemical modifications must be established. This requires the integration and reconciliation of molecular methods, experimental culture work, and geochemical fluid analysis. The intention of this manuscript is to present an isotopic dataset 
suggestive of active microbial methanogenesis and methane oxidation in diffuse hydrothermal fluids as a baseline example of the microbiological influence on the volatile geochemistry of hydrothermal vent systems.

Here we present the results of a natural experiment examining the carbon isotopic composition of low-temperature fluids that are located proximal to, and are a chemical dilution of, a high-temperature "parent" fluid. We attribute the isotopic depletions in $\delta^{13} \mathrm{C}_{\text {of }} \mathrm{CH}_{4}$ from low-temperature fluids, relative to values from high-temperature fluids, to microbial methanogenesis. Despite limited microbiological evidence of methanotrophy in hydrothermal environments, we hypothesize that the observed isotopic depletions in $\delta^{13} \mathrm{C}_{\text {of }} \mathrm{CO}_{2}$ from lowtemperature fluids, relative to values from high-temperature fluids, is suggestive of active methanotrophy.

\section{MATERIALS AND METHODS}

\subsection{Geologic setting}

The $9^{\circ} 50^{\prime} \mathrm{N}$ area of the EPR is perhaps the best example of a prototypical fast-spreading ridge (ALt, 1995). The symmetric ridge profile shallows to $\sim 2500 \mathrm{~m}$ water depth at the axis, and is characterized by a full spreading rate of $11 \mathrm{~cm} / \mathrm{yr}$ (CARBOTTE and MACDONALD, 1992), a shallow magma chamber located $\sim 1 \mathrm{~km}$ beneath the seafloor (DETRICK et al., 1987), extensive evidence of volcanism (FORNARI et al., 2004), and an $\sim 60 \mathrm{~m}$ wide axial summit trough (AST) that supports active hydrothermal vents.

The area between 9 $46^{\prime}-51^{\prime} \mathrm{N}$ was impacted by seafloor eruptive events in 1991 and 1992 (HAYMON et al., 1993), triggering a series of research expeditions to chronicle the dynamic 
chemical, biological, and geological responses to this volcanic perturbation. In the months preceding April 2006 a series of earthquakes signaled eruptive activity at this intensively studied area, and a series of response cruises sponsored by the Ridge2000 program verified extensive volcanism (Cowen et al., 2007; LiLley et al., 2006; Von DAmm et al., 2006). At the time of writing, it is unclear the extent to which the eruptive events have modified the specific vent sites described here. It is important to note that all data and descriptions of vent sites presented here are based on measurements and observations prior to the most recent eruptive events, and may not accurately depict their present state.

Samples analyzed herein are from vents located within the AST along an $\sim 8 \mathrm{~km}$ stretch of the EPR between $9^{\circ} 46^{\prime}-51^{\prime} \mathrm{N}$ (Figure 1). Two diffuse vents, Bio9R and Y, are ideally suited to examining the processes that modify high-temperature fluids in diffuse flow environments. Bio9R and Y vents are located directly adjacent to the high-temperature vents Bio9 and TWP, respectively. The diffuse vent Biomarker9 Riftia (Bio9R) adjoins the Bio9 vent site; Y vent is diffusely venting at the base of a lava pillar upon which the TWP sulfide structure and vent are located. The close proximity of low- and high-temperature fluids, and the absence of other vent sites within $10 \mathrm{~m}$ of Bio9/Bio9R and 20m of TWP/Y, allows for the safe assumption that the diffuse fluid (Bio9R, $\mathrm{Y})$ is the diluted and modified analog of the proximal high-temperature fluid (Bio9, TWP) (VON DAMM and LILLEY, 2004).

\subsection{Sample collection and analysis}

Accurate analysis of hydrothermal volatiles requires that both diffuse fluid samples and hightemperature black smoker samples be obtained using "gas-tight" sampling vessels. As samples are collected under high hydrostatic pressures, gas-tight samplers (GT) are designed to prevent 
degassing of the fluid during the subsequent release of pressure upon ascent. The gas-tight samplers (GT) employed in this study are fixed volume samplers that maintain the integrity of the fluid sample until it is quantitatively transferred to a shipboard vacuum extraction line where the volatile fraction is quantitatively removed. The GT samplers are constructed entirely of titanium and enclose a $150 \mathrm{~mL}$ sample volume that is spring sealed and hydraulically opened using a gold tipped piston that ensures degassing does not occur upon ascent. Gas-tight, samplers are most often deployed in high-temperature vent work as discrete samples where the 1/4-inch titanium tube inlet is positioned in the vent orifice and triggered by the vehicle's manipulator arm. All samples presented here were collected using the DSV Alvin; the sample number reflects the Alvin dive number followed by the numerical identity of the gas-tight sampler employed. Due to the low flow rates and poorly defined orifices of diffuse vents, the acquisition of good-quality diffuse samples requires special consideration. All of the lowtemperature fluids presented here were obtained using GT vessels mounted on the NOAA manifold system described in Massoth (1988) and Von Damm and Lilley (2004). The manifold system pumps diffuse fluids into a titanium manifold where temperature is monitored as a quality control, and multiple GT sample bottles may be triggered once a stable temperature has been reached.

Once shipboard, high-temperature and diffuse vent fluid samples were processed identically using the extraction procedure described here. Using internal standards this method was shown to be insensitive to the volatile concentrations, a concern as high-temperature samples can have orders of magnitude more gas, by volume, than diffuse samples. The fluid was quantitatively extracted from the GT sampler on a portable titanium and glass vacuum line. Extracted fluid was acidified to convert all carbonate species to $\mathrm{CO}_{2(\mathrm{aq})}$, agitated ultrasonically to 
move $>97 \%$ of the $\mathrm{CO}_{2}$ into the gas phase. This gas was subsequently passed through a $-60^{\circ} \mathrm{C}$ cold trap to remove water, and, using a mechanical bellows pump, moved to a set of calibrated volumes. After manometric determination of the volume, several aliquots were preserved in 30mL pyrex breakseal vials. Remaining degassed fluid was stored in acid rinsed HDPE bottles for shore-based determination of normalization elements $\mathrm{Mg}$ and Si using methods described in Von Damm (2000).

In a land-based laboratory glass vacuum line, breakseals were broken and the volatile samples were manipulated so that pure fractions of $\mathrm{CO}_{2}$ and $\mathrm{CH}_{4}$ could be measured by isotoperatio mass spectrometery (IRMS). A bellows pump was used to adjust the volume of sample to be analyzed, ideally $\sim 500 \mathrm{uL} \mathrm{CO} ~_{2}$ and $\sim 200 \mathrm{~nL} \mathrm{CH}_{4}$. After passing through a slush trap (to remove water), the condensable fraction $\left(\mathrm{CO}_{2}, \mathrm{H}_{2} \mathrm{~S}\right)$ was frozen out in a liquid nitrogen trap, and methane was trapped in a valved u-trap on silica gel under liquid nitrogen temperatures. The non-condensable fraction (primarily $\mathrm{H}_{2}$, and $\mathrm{N}_{2}$ ) was slowly evacuated using a metered valve to vacuum. The methane fraction frozen in the u-trap was analyzed on a continuous flow Finnigan Delta + XL mass spectrometer, using a combustion and pre-concentrating inlet system (BRAND, 1996). The $\mathrm{CO}_{2}$ and $\mathrm{H}_{2} \mathrm{~S}$ remaining in the vacuum line were separated by passing the gas over powdered $\mathrm{Ag}_{3} \mathrm{PO}_{4}$, effectively removing all $\mathrm{H}_{2} \mathrm{~S}$ by producing solid $\mathrm{Ag}_{2} \mathrm{~S}$. The $\mathrm{CO}_{2}$ was frozen into a valved finger and analyzed on a dual-inlet Finnigan 251 mass spectrometer. Using internal gas standards, mixed to approximate a hydrothermal sample and processed using the described method, analytical error was found to be $\pm 0.3 \%$ for $\delta^{13} \mathrm{C}_{\text {of }} \mathrm{CH}_{4}$ and better than $\pm 0.05 \%$ for $\delta^{13} \mathrm{C}_{\text {of }} \mathrm{CO}_{2}$. All samples were measured in triplicate, and the mean standard deviation of all triplicate measurements was in agreement with error analysis by internal 
standards. All measured ${ }^{13} \mathrm{C} /{ }^{12} \mathrm{C}$ ratios are reported in standard $\delta$ notation and \%o units, referenced to the vPDB scale.

\subsection{Data reduction and normalization}

During sampling, seawater is inevitably entrained into the sampler, and thus measured concentrations do not accurately reflect the composition of the pure vent fluid. For hightemperature samples, endmember concentrations presented here are calculated using established methods that assume pure vent fluid has a zero $\mathrm{Mg}$ concentration, and therefore seawater mixing during sampling is the source of all Mg present in the sample (BUTTERFIELD et al., 1994; LILLEY et al., 1993; VON DAMM, 2000). This method is effective for samples where minor amounts of seawater have been entrained during sampling because endmember values require only a small extrapolation. However, for diffuse fluids, where samples may only be a few percent by volume vent fluid, large extrapolations are required, and an alternate method for calculating endmember concentrations is preferred. The high precision of aqueous silica measurements (relative to magnesium measurements), and smaller extrapolations used in Si normalization (relative to $\mathrm{Mg}=0$ extrapolations) encourages the use of Si to normalize fluid data in the comparison of hightemperature and diffuse fluids (VON DAMM and LiLLEY, 2004). Here we assume that vent fluid $\mathrm{Si}$ is conservatively mixed with a $0.155 \mathrm{mmol} / \mathrm{kg}$ seawater endmember (as measured from sample 3547-12, a background seawater sample from 950’N). While Von Damm and Lilley (2004) normalized all fluid data to $\mathrm{Si}=1 \mathrm{mmol} / \mathrm{kg}$, a value that approximates the $\mathrm{Si}$ concentrations measured in low-temperature fluids, here we normalize the low-temperature data to the endmember Si concentration of the adjacent high-temperature fluid. Although this method 
of Si-normalization involves larger extrapolations for the low-temperature data (compared with normalization to $\mathrm{Si}=1 \mathrm{mmol} / \mathrm{kg}$ ), this approach has the advantage that endmember hightemperature gas concentrations can be directly compared with previously reported endmember hydrothermal volatile data.

It should be noted that endmember $\mathrm{CO}_{2}$ concentrations and $\delta^{13} \mathrm{C}$ values of $\mathrm{CO}_{2}$ have been corrected only for the seawater bicarbonate entrained during sampling and not for seawater bicarbonate that was present in the initial fluid. Although previous studies have made additional corrections to endmember $\mathrm{CO}_{2}$ values to include the seawater bicarbonate contained in the original parcel of downwelled fluid (EVANS et al., 1988; LILLEY et al., 1993; WELHAN and LUPTON, 1987), recent evidence from the Endeavour hydrothermal system (PROSKUROWSKI et al., 2004), Baby Bare (SANSONE et al., 1998) and several ODP drill cores (Alt and TEAgLE, 1999), suggest that correcting for original seawater bicarbonate is not appropriate. The diffuse samples presented here have low measured $\mathrm{CO}_{2}$ concentrations and high $\mathrm{Mg}$ concentrations, such that the molar amount of seawater bicarbonate entrained during sampling (as determined by $\mathrm{Mg}$ ) added to the $2.3 \mathrm{mmol} / \mathrm{kg}$ of bicarbonate assumed to be present in the original fluid accounts for nearly all, and in some cases, more than, the $\mathrm{CO}_{2}$ measured in the sample. This untenable result supports the hypothesis that seawater bicarbonate originally present in the downwelled fluid has been removed prior to venting at the seafloor. Assuming that the original bicarbonate has been removed, and applying just the Mg correction for entrained seawater to the ${ }^{13} \mathrm{C}$ measurement yields internally consistent values for the $\mathrm{Y}$ and Bio9R vents, whereas additional corrections for original bicarbonate result in implausible and inconsistent isotope values. 
Although the low-temperature samples have near-seawater $\mathrm{Mg}$ values, the correction applied to the ${ }^{13} \mathrm{C}$ isotope value of $\mathrm{CO}_{2}$ is done by the isotope-mass balance approach shown below, and does not involve large extrapolations:

$$
\begin{aligned}
& R_{\text {measured }}\left[\mathrm{CO}_{2}\right]_{\text {measured }}=R_{\text {vent }}\left[\mathrm{CO}_{2}\right]_{\text {vent }}+R_{\text {entrained }}\left[\mathrm{CO}_{2}\right]_{\text {entrained }} \\
& {\left[\mathrm{CO}_{2}\right]_{\text {measured }}=\left[\mathrm{CO}_{2}\right]_{\text {vent }}+\left[\mathrm{CO}_{2}\right]_{\text {entrained }}}
\end{aligned}
$$

Where $\mathrm{R}={ }^{13} \mathrm{C} /{ }^{12} \mathrm{C}, \mathrm{R}_{\text {measured }}$ and $\left[\mathrm{CO}_{2}\right]_{\text {measured }}$ denote the raw measured vent fluid values, $\mathrm{R}_{\text {vent }}$ and $\left[\mathrm{CO}_{2}\right]_{\text {vent }}$ denote the values for the pure vent fluid component, and $\mathrm{R}_{\text {entrained }}$ and $\left[\mathrm{CO}_{2}\right]_{\text {entrained }}$ denote the values for the entrained seawater bicarbonate component. The mass balance is solved for $\mathrm{R}_{\mathrm{vent}}$, as all other variables are known, given that $\mathrm{R}_{\text {entrained }}$ was measured at $0.9996(-0.40 \%$ ), and:

$$
\left[\mathrm{CO}_{2}\right]_{\text {entrained }}=\frac{[\mathrm{Mg}]_{\text {measured }}}{[\mathrm{Mg}]_{S W}}\left[\mathrm{CO}_{2}\right]_{S W}
$$

Where $\mathrm{Mg}_{\text {measured }}$ is the measured $\mathrm{Mg}$ value reported in Table $1, \mathrm{Mg}_{\mathrm{SW}}$ is the measured background seawater $\mathrm{Mg}$ value $(52.2 \mathrm{mmol} / \mathrm{kg})$ and $\left[\mathrm{CO}_{2}\right]_{\mathrm{SW}}$ is the measured background seawater bicarbonate concentration $(2.3 \mathrm{mmol} / \mathrm{kg})$. The errors, involved in this approach are $\pm 0.2 \%$ as determined by a Monte Carlo error analysis, and are tied mainly to the precision of the $\mathrm{Mg}$ measurement. Isotope values for $\mathrm{CH}_{4}$ are not corrected, as seawater $\mathrm{CH}_{4}$ concentrations are, at least, three orders of magnitude smaller than measured vent $\mathrm{CH}_{4}$ concentrations.

Uncorrected (measured) data are presented in Table 1, and endmember data (concentrations of high-temperature fluids normalized to $\mathrm{Mg}=0$; concentrations of lowtemperature fluids normalized to the endmember Si value of the proximal high-temperature vent; and $\mathrm{CO}_{2}$ isotope values corrected for the contribution of entrained seawater bicarbonate) are 
presented in Table 2. Unless specifically noted, all subsequent discussion of data pertains to the endmember values.

\section{RESULTS}

\subsection{Endmember gas concentrations}

Endmember gas concentrations and isotope compositions from high-temperature black smoker vents (Bio9, TWP) and proximal low-temperature diffuse flow vents (Bio9R, Y) from the BIOGEOTRANSECT study area near $9^{\circ} 50^{\prime} \mathrm{N}$ along the EPR are presented in Table 2 . For comparative purposes, original data from $\mathrm{Q}, \mathrm{A}$, and $\mathrm{V}$ vents (located within $\sim 5 \mathrm{~km}$ the Bio9Bio9R vents) and previously published data from sites along the East Pacific Rise, the MidAtlantic Ridge, and the Juan de Fuca Ridge are also presented. These samples represent a subset of a time series beginning in 1991, directly following a large eruptive event centered at $9^{\circ} 50^{\prime} \mathrm{N}$ (HAYMON et al., 1993), and ending in 2000.

The high-temperature vents in the study region have high endmember $\mathrm{CO}_{2}$ concentrations, ranging from $45 \mathrm{mmol} / \mathrm{kg}$ up to $185 \mathrm{mmol} / \mathrm{kg}$. The lowest $9^{\circ} 50^{\prime} \mathrm{N} \mathrm{CO}_{2}$ values approximate the observed gas concentrations at Endeavour during periods of sub-seafloor magmatism (LILLEY et al., 2003), and are significantly greater that 5-20 mmol $/ \mathrm{kg}$ values typically reported from hydrothermal vents (Von DAMM, 1995). The highest $\mathrm{CO}_{2}$ concentrations reported here aproximate the high values reported from Axial Seamount, a volcanically active vent site believed to have a near-continuous supply of magmatic $\mathrm{CO}_{2}$ (BUTTERFIELD et al., 1990; BUtTERFIELD et al., 2004). The low-temperature diffuse vents at $9^{\circ} 50^{\prime} \mathrm{N}$ also exhibit high $\mathrm{CO}_{2}$ concentrations when normalized to the Si content of the neighboring high-temperature vent. In general, the $\mathrm{CO}_{2}$ concentration of the diffuse fluid approximates the concentration of the 
proximal high-temperature endmember; however, the large extrapolations used in calculating diffuse endmember concentrations discourage a more detailed assessment.

Endmember $\mathrm{CH}_{4}$ concentrations range from 0.05 to $0.12 \mathrm{mmol} / \mathrm{kg}$ for post- $1991 \mathrm{high}-$ temperature samples (Bio9 and TWP) and 0.06 to $1.87 \mathrm{mmol} / \mathrm{kg}$ for post-1991 low-temperature samples (Bio9R and Y). Methane concentrations in 1991, sampled directly after eruptive activity, are ubiquitously high, with the high-temperature vent samples averaging $0.13 \mathrm{mmol} / \mathrm{kg}$ and a 1991 mean diffuse vent $\mathrm{CH}_{4}$ concentration of $5.86 \mathrm{mmol} / \mathrm{kg}$. The $1991 \mathrm{Y}$ and $\mathrm{V}$ vent values (10.20 and $1.52 \mathrm{mmol} / \mathrm{kg}$, respectively) are similar to the mmolar $\mathrm{CH}_{4}$ levels at sediment influenced vents such as those at Main Endeavour Field (LILLEY et al., 1993) and Guaymas Basin (VON DAMM et al., 1985; WeLHAN and LuPTON, 1987). Methane concentrations of post1991 Y vent samples are two to three times those of TWP, the adjacent high-temperature vent, while the low-temperature Bio9 $\mathrm{R}$ vent has similar $\mathrm{CH}_{4}$ concentrations to its high-temperature analog, Bio9 vent. The low $\mathrm{CH}_{4}$ values, $0.05-0.16 \mathrm{mmol} / \mathrm{g}$, associated with many of the vents near $9^{\circ} 50^{\prime} \mathrm{N}$ are similar to reported values along the EPR at $11^{\circ} \mathrm{N}, 13^{\circ} \mathrm{N}$ and $21^{\circ} \mathrm{N}$ (LILLEY et al., 1983; Merlivat et al., 1987; Welhan and Craig, 1979; Welhan and Craig, 1983), the MidAtlantic Ridge (MAR) at MARK, TAG and Broken Spur (CHARLOU et al., 1996; JAMES et al., 1995; JeAn-BAPTiste et al., 1991), and the Juan de Fuca Ridge at South Cleft and Axial Volcano (BUTTERFIELD et al., 2004; EVANS et al., 1988).

Hydrogen concentration data reveal two trends: 1) low-temperature samples have extremely depleted $\mathrm{H}_{2}$ levels compared with their high-temperature analogs, and 2) elevated $\mathrm{H}_{2}$ concentrations observed in 1991 high-temperature samples systematically decrease in subsequent years. Hydrogen concentration plotted against measured vent temperature (Figure 2) clearly shows the difference in hydrogen concentration between high-temperature and diffuse vents. 
Highly extrapolated endmember $\mathrm{H}_{2}$ concentrations of $9^{\circ} 50^{\prime} \mathrm{N}$ low-temperature vents range from $0.01 \mathrm{mmol} / \mathrm{kg}$ to $0.16 \mathrm{mmol} / \mathrm{kg}$, values that are low compared to basalt hosted sites not influenced by recent seafloor eruption events (BUTTERFIELD et al., 2004; CHARLOU et al., 2000;

Charlou et al., 2002; Evans et al., 1988; Lilley et al., 1993; Von Damm, 1995). Post eruptive high-temperature vents exhibit $\mathrm{H}_{2}$ concentrations of 0.08 to $0.51 \mathrm{mmol} / \mathrm{kg}$, excluding the anomalously high 3.42-8.36 mmol/ $\mathrm{kg}$ concentrations observed at TWP. Hydrogen concentrations during periods of eruptive activity in 1991 and 1992 are similar to those observed at TWP, ranging from $1.40-2.80 \mathrm{mmol} / \mathrm{kg}$ at Bio9, to $3.01 \mathrm{mmol} / \mathrm{kg}$ at $\mathrm{Q}$ vent, and greater than $27 \mathrm{mmol} / \mathrm{kg}$ at $\mathrm{A}$ vent, the site of the highest reported hydrothermal vent $\mathrm{H}_{2}$ concentrations (LILLEY et al., 2003).

\subsection{Stable carbon isotopic composition}

The carbon isotopic compositions of methane and carbon dioxide from $9^{\circ} 50^{\prime} \mathrm{N}$ samples are summarized in Figure 3 and Table 2. The reported $\delta^{13} \mathrm{C}$ values of $\mathrm{CO}_{2}$ have been corrected to a zero $\mathrm{Mg}$ endmember composition using measured background $\mathrm{EPR}$ seawater $\mathrm{CO}_{2}$ concentration and $\delta^{13} \mathrm{C}$ value of $\mathrm{CO}_{2}(2.3 \mathrm{mmol} / \mathrm{kg}$ and $-0.40 \%$, respectively). High-temperature vents sampled between 1992 and 2000 have a well-constrained carbon isotopic composition, a $\delta^{13} \mathrm{C}$ value of $\mathrm{CO}_{2}$ of $-4.08 \pm 0.16 \%$ and a $\delta^{13} \mathrm{C}$ value of $\mathrm{CH}_{4}$ of $-20.1 \pm 1.2 \%$. Compared to neighboring high-temperature vents, $9^{\circ} 50^{\prime} \mathrm{N}$ diffuse fluids are depleted in ${ }^{13} \mathrm{C}$ in both $\mathrm{CO}_{2}$ and $\mathrm{CH}_{4}$, with an average $\delta^{13} \mathrm{C}$ value of $\mathrm{CO}_{2}$ of $-4.55 \pm 0.53 \%$, and an average $\delta^{13} \mathrm{C}$ value of $\mathrm{CH}_{4}$ of $-30.2 \pm 2.7 \%$. Due to extremely large amounts of high-temperature fluids exiting the crust through cracks and fissures, rather than well-defined vent orifices (HAYMON et al., 1993), focused flow fluids were difficult to sample in 1991. Samples from the Bio9 cluster $\left(368^{\circ} \mathrm{C}\right)$ and 
A vent $\left(396^{\circ} \mathrm{C}\right)$, taken shortly after the 1991 seafloor eruption, are isotopically distinct from samples taken on subsequent visits. Methane from Bio9 in 1991 (a $\delta^{13} \mathrm{C}$ value of $-34.6 \%$ ) is depleted in ${ }^{13} \mathrm{C}$ relative to high-temperature samples subsequent to 1991 , resembling the methane isotopic composition of diffuse samples. Similarly, $1991 \mathrm{~A}$ vent $\mathrm{CH}_{4}\left(\delta^{13} \mathrm{C}\right.$ value of $-26.5 \%$ ) is more depleted in ${ }^{13} \mathrm{C}$ relative to any other high-temperature vent $\mathrm{CH}_{4}$ measured in this study.

The $\delta^{13} \mathrm{C}$ values of $\mathrm{CO}_{2}$ presented here are among the heaviest measured at hydrothermal vents (Charlou et al., 2002; Charlou et al., 1996; JeAn-BAPTiste et al., 1991; LiLley et al., 1993; Shanks et al., 1995; TAYlor, 1986; WelHAN and Craig, 1983; WelHAN and LuPTON, 1987), and are very similar to the $-4 \%$ values measured in highly vessiculated basalt "popping rocks" thought to represent the average composition of undegassed $\mathrm{CO}_{2}$ residing in the upper crust (Javoy and Pineau, 1991; Pineau and Javoy, 1994; Sarda and Graham, 1990). The high concentrations of $\mathrm{CO}_{2}$ enriched in ${ }^{13} \mathrm{C}$ relative to other hydrothermal sites suggest an undegassed, primordial, magmatic source of $\mathrm{CO}_{2}$. This conclusion is supported by the geologic evidence of fast spreading rate (CARBOTTE and MACDONALD, 1992), active volcanism (FORNARI et al., 2004; ForNARI et al., 1998; HAYMON et al., 1993; VON DAMM, 2000; VON DAMM et al., 1995), and shallow heat source (LILLEY et al., 2003; Von DAmM, 2004) at $9^{\circ} 50^{\prime} \mathrm{N}$. The constant $\mathrm{CO}_{2}$ isotope and concentration values at high-temperature vents over the $7+$ year sampling period imply that the magmatic source of $\mathrm{CO}_{2}$ is often replenished so that the melt reservoir is not appreciably degassed, a process that would deplete both the concentration and the isotopic composition of $\mathrm{CO}_{2}$ (BUTTERFIELD et al., 1990; JAVOY et al., 1978; KELLEY and FRÜHGreen, 1999; Kelley and Früh-Green, 2000; Kelley and FrüH-Green, 2001).

\section{DISCUSSION}


The aim of this manuscript is to report the isotopic compositions of $\mathrm{CH}_{4}$ and $\mathrm{CO}_{2}$ at diffuse vents and proximal high-temperature sites, and interpret the observed isotopic depletions of the lowtemperature volatiles in the context of relevant chemical, and biological processes. The sample set presented here was carefully chosen to create a seafloor experiment with the hightemperature fluid as the control. The close proximity $(<1 \mathrm{~m})$ of TWP to Y vent and of Bio9 to Bio9R, as well as the absence of other vents within $20 \mathrm{~m}$ of TWP/Y and 10m of Bio9/Bio9R, suggests that the low-temperature fluid is derived locally from the high-temperature fluid. Furthermore, the ratios of conservative tracers such as temperature, $\mathrm{Si}$, and Mn (VON DAMM, 1995 ) are invariant (for $\mathrm{T} / \mathrm{Si}$ and $\mathrm{Mn} / \mathrm{Si}$ ) between the high-temperature fluid and the diffuse fluid, supporting the hypothesis that the diffuse fluids at Bio9R and $\mathrm{Y}$ vents are a dilution of the high-temperature endmember (VON DAMM and LILLEY, 2004). In contrast, concentrations of bio-active and chemically reactive elements such as $\mathrm{Fe}, \mathrm{H}_{2} \mathrm{~S}, \mathrm{CO}_{2}, \mathrm{CH}_{4}$, and $\mathrm{H}_{2}$ show dramatic differences between the low-temperature and high-temperature vent environments. Von Damm and Lilley (2004) conclude that iron in diffuse fluids is lost to mineral precipitation, and that biological activity at the low-temperature sites leads to consumption of $\mathrm{H}_{2} \mathrm{~S}, \mathrm{H}_{2}$, and $\mathrm{CO}_{2}$ and production of $\mathrm{CH}_{4}$. Here we present isotopic data that support Von Damm and Lilley's (2004) hypothesis of microbial methanogenesis at the diffuse sites and further suggest that microbial methanotrophy may be an active process in the low-temperature fluids.

\subsection{Potential Mechanisms of Isotopic Modification of Vent Fluids}

The depletions in ${ }^{13} \mathrm{C}_{\text {of }} \mathrm{CH}_{4}$ and $\mathrm{CO}_{2}$ observed at diffuse sites relative to high-temperature sites at $9^{\circ} 50^{\prime} \mathrm{N}$ vent sites may be attributed to three mechanisms: temperature dependent isotopic 
equilibration, the mixing of isotopically distinct sources, and isotopic fractionation during chemical or metabolic reactions.

Temperature dependent isotopic fractionation can be confidently ruled out as a mechanism to deplete the carbon isotopic composition of low-temperature fluids based on data presented in Figure 3. The expected isotopic fractionations at given temperatures are plotted based on the calculations of Horita (2001), demonstrating that the isotopic composition of neither the high-temperature $\left(300-400^{\circ} \mathrm{C}\right)$ nor the low-temperature fluids $\left(20-55^{\circ} \mathrm{C}\right)$ is accurately approximated by the isotopic equilibrium temperature. The fractionation between $\mathrm{CO}_{2}$ and $\mathrm{CH}_{4}$ from high-temperature samples from $9^{\circ} 50^{\prime} \mathrm{N}$ (with the notable exception of the 1991 sample) is compatible with equilibrium fractionation at temperatures ranging from $420-585^{\circ} \mathrm{C}$. While these predicted temperatures fall within the range between the highest measured hydrothermal vent temperatures and temperatures observed in deeply penetrating hydrothermal fluids (GILLIS and ROBERTS, 1999; MANNING et al., 1996), they are, on average, $140^{\circ} \mathrm{C}$ greater than the corresponding measured temperature. At low-temperature sites the equilibrium isotopic fractionation predicted temperatures ranges $240-375^{\circ} \mathrm{C}$, with the predicted temperature being, on average, $270^{\circ} \mathrm{C}$ higher than the measured value. The result of apparent $\mathrm{CO}_{2}-\mathrm{CH}_{4}$ isotopic disequilibrium is not unexpected, as the kinetics of the uncatalyzed $\mathrm{CO}_{2}-\mathrm{CH}_{4}$ isotope exchange reaction at temperature less than $400-500^{\circ} \mathrm{C}$, and the metal catalyzed reaction at temperatures less than $200^{\circ} \mathrm{C}$, are exceedingly slow in laboratory experiments (HORITA, 2001; SACKETT, 1993). The increasingly sluggish kinetics of $\mathrm{CO}_{2}-\mathrm{CH}_{4}$ isotope exchange as temperature decreases precludes temperature dependent isotope fractionation at diffusely venting lowtemperature sites, and suggests that $\mathrm{CO}_{2}-\mathrm{CH}_{4}$ carbon isotopic equilibrium is not well established even at high-temperature vent sites. 
The mixing of isotopically distinct sources is a common mechanism by which the isotopic signature of a natural sample can be modified. For the purposes of this discussion "mixing" refers to the addition of externally sourced $\mathrm{CO}_{2}$ and $\mathrm{CH}_{4}$ to the high-temperature vent fluid (rather than $\mathrm{CO}_{2}$ and $\mathrm{CH}_{4}$ produced by thermal or biological processes within the hightemperature fluid and subsequently incorporated). Because the low-temperature fluids are depleted in ${ }^{13} \mathrm{C}$ in both $\mathrm{CH}_{4}$ and $\mathrm{CO}_{2}$ relative to the high-temperature fluid, an external source must be depleted in ${ }^{13} \mathrm{C}$ in both $\mathrm{CH}_{4}$ and $\mathrm{CO}_{2}$ relative to the low-temperature fluid if a mixing model is assumed. Seawater cannot be this external source, as there is no appreciable $\mathrm{CH}_{4}$ contribution from seawater, and seawater bicarbonate is enriched in ${ }^{13} \mathrm{C}$ relative to the hightemperature $\mathrm{CO}_{2}$. Moreover, because the mixing trajectories described by the $\delta^{13} \mathrm{C}$ values of $\mathrm{CH}_{4}$ and $\mathrm{CO}_{2}$ of the Bio9/Bio9R and Y/TWP vent pairs are divergent, a mixing model with a single external source is not a viable model. Thus, either a) multiple sources, variably depleted in ${ }^{13} \mathrm{C}$ in both $\mathrm{CO}_{2}$ and $\mathrm{CH}_{4}$, relative to the high-temperature samples, are available for mixing at each site, or b) reaction based fractionating mechanisms must be considered to explain the observed depletions in ${ }^{13} \mathrm{C}$ at the diffuse sites relative to the high-temperature sites.

We suggest that there are only two possible external sources of $\mathrm{CO}_{2}$ depleted in ${ }^{13} \mathrm{C}$ relative to the -4.5 to $-3.7 \%{ }^{13} \mathrm{C}$ values of $\mathrm{CO}_{2}$ from $9^{\circ} 50$ ' $\mathrm{N}$ high-temperature vents: highly evolved magmatic $\mathrm{CO}_{2}$ and thermogenic $\mathrm{CO}_{2}$. Magmatic $\mathrm{CO}_{2}$ becomes increasingly depleted in ${ }^{13} \mathrm{C}$ as it degasses (Bottinga and Javoy, 1989; Pineau and Javoy, 1983; Pineau et al., 1976); however, a scenario where highly evolved magmatic $\mathrm{CO}_{2}$ is input solely to diffuse fluids is extremely unlikely. Therefore, the thermal maturation of organic matter, producing both $\mathrm{CO}_{2}$ and $\mathrm{CH}_{4}$, is required if a mixing model is to be invoked to describe the isotopic data. 


\subsection{Assessing a Thermogenic Source of $\mathrm{CH}_{4}$ and $\mathrm{CO}_{2}$ to $\mathrm{Bio} 9 \mathrm{R}$ and $\mathrm{Y}$ vents}

We suggest that thermogenic production of carbon at $9^{\circ} 50^{\prime} \mathrm{N}$ diffuse vents is unlikely to be more than a minor source for the following reasons: a) the lack of a stable and sufficeintly large source of organic carbon, b) the lack of increased nutrient concentrations in diffuse vents, suggesting that fresh biomass is not being pyrolyzed, c) the thermal alteration of organic matter is constrained to temperatures above $50^{\circ} \mathrm{C}$ and, d) the observed depletions in ${ }^{13} \mathrm{C}$ of $\mathrm{CO}_{2}$ in diffuse fluids relative to high-tempearture fluids are not adequately described by a thermogenic source.

The lack of sediments along the fast-spreading ridge precludes the necessary accumulation of sedimentary organic matter (HAYMON et al., 1993). Despite the lack of sediments along the ridge axis the potential for organic matter to interact with hydrothermal fluids does exist. In 1991, a 1-10 cm thick lava flow at the aptly named Tubeworm BBQ site $(<1 \mathrm{~km}$ north of Bio9) was observed to envelop areas colonized by vent megafauna (HAYMON et al., 1993), creating a potential reservoir of organic matter. However, the organic matter reservoir created by infrequent eruptive events is likely too small and too episodic to account for the steady-state isotopic depletion seen in diffuse fluids six years after the 1991 eruption.

Another potential source of organic carbon to this system is dissolved organic carbon (DOC), which has typical deep Pacific seawater concentrations of 33-36 $\mu \mathrm{mol} / \mathrm{kg}$ (HANSELL and CARlson, 1998; LANG et al., 2006). Measurements from the Main Endeavour Field show that high-temperature fluid DOC concentrations $(\sim 14 \mu \mathrm{mol} / \mathrm{kg})$ are less than seawater concentrations, while diffuse fluid DOC concentrations $(\sim 46 \mu \mathrm{mol} / \mathrm{kg})$ are greater than seawater concentrations (LANG et al., 2006). Thermal degradation of DOC at high-temperatures is hypothesized as a potential sink of DOC at high-temperature vent sites; however, elevated DOC concentrations at 
diffuse sites suggest that these thermogenic processes are not active at low-temperatures and that biological production is the likely source of the additional DOC (LANG et al., 2006). Even if seawater DOC was being thermogenically converted to $\mathrm{CH}_{4}$ in diffuse fluids, a $\sim 30 \mu \mathrm{mol} / \mathrm{kg}$ DOC source of organic carbon is still only a fraction of the $100-260 \mu \mathrm{mol} / \mathrm{kg}$ differences in $\mathrm{CH}_{4}$ concentrations observed at TWP/Y vents.

Low-level "nutrient" concentrations argue against a thermogenic source of $\mathrm{CH}_{4}$ via the pyrolysis of microbial biomass at $9^{\circ} 50^{\prime} \mathrm{N}$ diffuse vents. The pyrolytic products of living biomass should include nitrogen and phosphorous approximating the Redfield ratio. However, measurement of $\mathrm{NH}_{4}{ }^{+}$and $\mathrm{PO}_{4}^{-3}$ concentrations show no enrichment in $9^{\circ} 50^{\prime} \mathrm{N}$ diffuse fluids when compared to the high temperature fluid and are often depleted relative to the background seawater value (VON DAMM and LILLEY, 2004).

The potential for thermogenic $\mathrm{CH}_{4}$ and $\mathrm{CO}_{2}$ production by the pyrolysis of microbial biomass or DOC exists where microbial communities intersect transient fluxes of heat, such as the shallow ocean crust and, in particular, diffuse flow sites. However, the thermogenic production of volatile carbon during sediment diagenesis at less than $50^{\circ} \mathrm{C}$ is extremely limited (Hunt, 1995; Schimmelmann et al., 2006; SEewald, 2003). Analysis of organic matter exposed to temperatures of $50-80^{\circ} \mathrm{C}$ at Middle Valley, a sedimented hydrothermal system along the northern segment of the Juan de Fuca Ridge, showed the absence of typical petroleum markers of thermogenic activity such as polycyclic aromatic hydrocarbons (SIMONEIT et al., 1992). These results suggest that a possible source of thermogenic volatiles to the diffuse vents described here must be constrained to a stable zone of mixing $80-400^{\circ} \mathrm{C}$ with a steady supply of organic matter. Despite counter-indications from direct seafloor observations, it is concievable that thermogenically favorable conditions do exisit at $9^{\circ} 50^{\prime} \mathrm{N}$, such as in sub-surface 
pockets rich in microbial biomass. However, we suggest that the observed $\delta^{13} \mathrm{C}$ values of $\mathrm{CO}_{2}$ are not compatible a thermogenic source. Thermal organic matter degradation experiments at temperatures $>100^{\circ} \mathrm{C}$, show that in addition to $\mathrm{CH}_{4}, \mathrm{CO}_{2}$ is produced in a near 1:1 ratio, with $\delta^{13} \mathrm{C}$ values of $\mathrm{CO}_{2}-15$ to -5\% (ANDRESEn et al., 1993; ChUng and SACKeTt, 1979; HunT, 1995). Considering the maximum increase in $\mathrm{CH}_{4}$ between a high-temperature fluid and its diffuse fluid analog is $0.2 \mathrm{mmol} / \mathrm{kg}$, mixing a similar amount of byproduct $\mathrm{CO}_{2}$ with the large $(100+\mathrm{mmol} / \mathrm{kg})$ reservoir of $\mathrm{CO}_{2}$ present in the fluid would deplete the $\delta^{13} \mathrm{C}$ values of $\mathrm{CO}_{2}$ by a maximum of $0.03 \%$, an order of magnitude less than the $0.5 \%$ mean isotopic shift observed.

If a thermogenic source is only a minor contributor to the isotopic depletions at $\mathrm{Y}$ and Bio9R vents, then a pure mixing model between high-temperature endmembers and external $\mathrm{CH}_{4}$ and $\mathrm{CO}_{2}$ sources cannot fully describe the observed isotopic data.

\subsection{Origin of $\mathrm{CH}_{4}$ at $9^{\circ} 50^{\prime} \mathrm{N}$}

High-temperature samples are characterized by low $(<0.1 \mathrm{mmol} / \mathrm{kg}) \mathrm{CH}_{4}$ concentrations and $\delta^{13} \mathrm{C}$ values of $\mathrm{CH}_{4}$ averaging $-20 \%$, strongly suggesting that the $\mathrm{CH}_{4}$ is of magmatic origin.

Methane venting at high-temperature $9^{\circ} 50^{\prime} \mathrm{N}$ sites is similar in stable carbon isotopic composition to fluids measured at unsedimented mid-ocean ridge hydrothermal systems, such as the Southern Juan de Fuca Ridge (-20.8 to -17.8\%) (Evans et al., 1988), the EPR at $21^{\circ} \mathrm{N}(-17.6$ to $-15.0 \%$ ) (Welhan and Craig, 1983$)$, the EPR at $13^{\circ} \mathrm{N}(-19.5$ to $-16.6 \%$ ) (MERLIVAT et al., 1987), the MAR at Broken Spur (-19 to -18\%) (JAMES et al., 1995), and the MAR at MenezGwen (-19.6 to -18/8\%) (CHARLOU et al., 2000) (see Table 2).

In order to explain the general trend of diffuse volatiles being depleted in ${ }^{13} \mathrm{C}$ relative to high-temperature samples, we invoke the microbial processes of methanogenesis and methane 
oxidation. Methanogenesis must be the dominant microbial process as both low-temperature sites presented in this study are characterized by elevated $\mathrm{CH}_{4}$ concentrations and decreased $\mathrm{H}_{2}$ concentrations relative to their high-temperature analog. Methanogenesis, the microbial reduction of low-molecular weight oxidized carbon species (primarily $\mathrm{CO}_{2}$ and acetate) to methane, has been cited as a classic example of high-temperature chemolithoautotrophy since the first hyperthermophile was cultured from $21^{\circ} \mathrm{N}$ EPR hydrothermal vent fluid (JONES et al., 1983). Methanogens are obligate anaerobes that include mesophiles, thermophiles, and hyperthoermophiles (WHITMAN et al., 1992). In addition to the successful isolation and enrichment of methanogens from ridge-crest low-temperature environments (HOLDEN et al., 1998; JEANTHON et al., 1999; JEANTHON et al., 1998; JONES et al., 1989; SUMmit and BAROSS, 1998), methanogens have been detected using molecular methods in the high-temperature samples from vent fluids and sulfide chimneys (HUBER et al., 2002; SCHRENK et al., 2003; TAKAI and HORIKOSHI, 1999).

Microbiological methanogenesis, in its simplest form, proceeds according to the straightforward reduction of carbon dioxide:

$$
\mathrm{CO}_{2}+4 \mathrm{H}_{2} \Leftrightarrow \mathrm{CH}_{4}+2 \mathrm{H}_{2} \mathrm{O}
$$

While an alternate, aceticlastic, pathway is important in many methanogenic environments, the reduction of $\mathrm{CO}_{2}$ is favored over acetate in moderately thermal environments (FEY et al., 2004), and extreme thermophiles capable of aceticlastic methane production have yet to be isolated (VALENTINE et al., 2004). As illustrated in the above reaction, biogenic methane production consumes large amounts of hydrogen relative to the carbon dioxide reduced or the methane produced. At the Bio9/Bio9R and TWP/Y sites milli-molar decreases in hydrogen concentration at the diffuse site relative to the high-temperature site do not consistently correspond with the 
appropriate differences in methane and $\mathrm{CO}_{2}$ concentrations. The lack of a precise stoichiometric $\mathrm{CH}_{4}$ gain and $\mathrm{CO}_{2}$ loss relative to hydrogen consumption during methanogenesis is likely due to the error involved in calculating comparable high-temperature and low-temperature endmember concentrations, and may be further obscured by the potential for hydrogen consumption by other microbial processes (e.g. thermophilic sulfate reduction).

Unlike the concentration data, the ${ }^{13} \mathrm{C}$ composition of $\mathrm{CH}_{4}$ is unaffected by seawater mixing and thus can be a sensitive and robust indicator of microbial activity. Figures 4 and 5 contrast the isotopic composition of adjacent high-temperature and diffuse fluids, illustrating the concentration and isotopic differences between $\mathrm{Y}$ and TWP and Bio9R and Bio9 fluids. The low-temperature fluid at $\mathrm{Y}$ vent is depleted in ${ }^{13} \mathrm{C}$ by an average of $11.7 \%$ in $\delta^{13} \mathrm{C}$ of $\mathrm{CH}_{4}$, and $0.37 \%$ in $\delta^{13} \mathrm{C}$ of $\mathrm{CO}_{2}$, relative to TWP over a sampling period of three years. Similar results are observed at Bio9R, where the low-temperature fluid is depleted in ${ }^{13} \mathrm{C}$ by $4.3 \%$ in $\delta^{13} \mathrm{C}_{\text {of }} \mathrm{CH}_{4}$, and by $0.90 \%$ in $\delta^{13} \mathrm{C}$ of $\mathrm{CO}_{2}$, relative to samples taken at Bio9 between 1994 and 1997.

Natural methane samples with $\delta^{13} \mathrm{C}$ values of $\mathrm{CH}_{4}$ less than $-50 \%$ are typically ascribed to methanogenic production (Cicerone and OREMLAND, 1988; SCHOELl, 1980; SCHOELl, 1988; WHITICAR, 1990). However, the majority of natural samples are from low-temperature environments such as rice paddy soils and marine sediments utilizing $\mathrm{CO}_{2}$ substrates with typical $\delta^{13} \mathrm{C}$ values near -20\% (SCHOELL, 1980). Methanogens in hydrothermal environments primarily utilize magmatic $\mathrm{CO}_{2}$ with $\delta^{13} \mathrm{C}$ values of -9 to $-4 \%$, and thus would be expected to produce $\mathrm{CH}_{4}$ enriched in ${ }^{13} \mathrm{C}$ relative to $\mathrm{CH}_{4}$ from low-temperature methanogenesis in sediments. The -32 to $25 \%$ o $\delta^{13} \mathrm{C}$ values of $\mathrm{CH}_{4}$ from $9^{\circ} 50^{\prime} \mathrm{N}$ diffuse fluids are enriched in ${ }^{13} \mathrm{C}$ relative to values typically ascribed to methane of biogenic origin, but are compatible with methanogenesis of a substrate $-4 \%$ 
in $\delta^{13} \mathrm{C}$ of $\mathrm{CO}_{2}$ and a fractionation factor at the low end of the range $1.023 \leq \alpha \leq 1.064$ determined by Valentine et al. (2004).

\subsection{Is methanogenesis coupled with methane oxidation?}

The depletions in ${ }^{13} \mathrm{C}$ observed in $\mathrm{CO}_{2}$ from diffuse fluids, relative to $\mathrm{CO}_{2}$ from high-temperature fluids, cannot be explained if just methanogenesis is invoked. Methanogenesis alone would either a) have no observable effect on the ${ }^{13} \mathrm{C}$ composition of $\mathrm{CO}_{2}$, as the amount of $\mathrm{CO}_{2}$ consumed is insignificant compared with the large $\mathrm{CO}_{2}$ pool, or b) slightly enrich the $\mathrm{CO}_{2}$ reservoir in ${ }^{13} \mathrm{C}$ as light $\mathrm{CO}_{2}$ molecules are is preferentially metabolized. However, the observed $\delta^{13} \mathrm{C}$ values of $\mathrm{CO}_{2}$ in diffuse fluids are depleted up to $0.9 \%$, a result that requires an additional process.

We hypothesize that methanogenesis is coupled with methane oxidation. Microbial methane oxidation can occur both aerobically and anaerobically. Aerobic microbial methane oxidation has been investigated extensively in numerous environments, including hydrothermal plumes (COWEN et al., 2002; DE ANGELIS et al., 1993), and basalt-hosted hydrothermal vent fluids (ELSAIED et al., 2005; NERCESSIAN et al., 2005). Anaerobic methane oxidation is less well understood, as no anaerobic methane oxidizers have been cultured (ALPERIN et al., 1988; GIRGUIS, 2003; VALENTINE et al., 2000). Although oxygenated seawater is mixed into diffuse fluids, oxygen is rapidly consumed heterotrophically or by reaction with reduced chemicals, and is not detectible in diffuse fluids above $8-12^{\circ} \mathrm{C}$ (CORLISS et al., 1979; JOHNSON et al., 1988). Although diffuse fluids hosting methanogens are requisitely anaerobic, based on the frequent identification of microaerobic or denitrifying microbes in diffuse fluids $>20^{\circ} \mathrm{C}$ (CAMPBELL et al., 
2006), it is likely that microaerobic zones exist in the subseafloor where methane could be oxidized aerobically.

Both aerobic and anaerobic methane oxidation metabolisms isotopically fractionate the $\mathrm{CH}_{4}$ substrate, producing $\mathrm{CO}_{2}$ relatively depleted in ${ }^{13} \mathrm{C}$. Carbon isotope fractionation factors vary from 1.005 to 1.031 for aerobic methane oxidation (determined experimentally) (BARKER and FritZ, 1981; Coleman et al., 1981) and from 1.0088 to 1.014 for anaerobic methane oxidation (determined from natural sediment analysis) (ALPERIN et al., 1988; MARTENS et al., 1999; WhitiCAR and FABER, 1986). Simply, the $\mathrm{CH}_{4}$ substrate will be enriched in ${ }^{13} \mathrm{C}$ as methane oxidation proceeds, and the $\mathrm{CO}_{2}$ produced will be depleted in ${ }^{13} \mathrm{C}$ relative to the $\mathrm{CH}_{4}$ pool. This pattern of isotopic fractionation is consistent with the $\delta^{13} \mathrm{C}$ values of diffuse fluid $\mathrm{CO}_{2}$ that are depleted in ${ }^{13} \mathrm{C}$ relative to the high-temperature fluid, as well as $\delta^{13} \mathrm{C}$ values of diffuse fluid $\mathrm{CH}_{4}$ that are enriched in ${ }^{13} \mathrm{C}$ relative to values predicted from a mid-range methanogenic fractionation factor $(\alpha=1.044)$ (VALENTINE et al., 2000).

Unlike the abundant evidence for methanogenesis in hydrothermal environments, evidence of methanotrophy, and specifically anaerobic methane oxidation, has been elusive. Although anaerobic methane oxidizers have not yet been identified in mid-ocean ridge hydrothermal vent fluids, recent investigations have shown ANME groups to be present in deepsea environments such as the $\operatorname{cool}\left(<10^{\circ} \mathrm{C}\right)$ carbonate chimneys at the Lost City Hydrothermal Field (BRAZELTON et al., 2006), the sediments of a mud volcano (NIEMANN et al., 2006), and the gas seeps of the Black Sea (MicHAELIS et al., 2002). Anaerobic methanotrophs have yet to be successfully isolated in culture, likely because a consortium of archaea and sulfate-reducing bacteria mediate the oxidation of $\mathrm{CH}_{4}$ (BoETIUS et al., 2000; MiCHAELIS et al., 2002; NiEMANN et al., 2006; ORPHAN et al., 2001). The coupling of anaerobic methane oxidation to the presence of 
sulfate is important in the context of diffuse fluids which, due to seawater mixing, have high sulfate concentrations relative to sulfate depleted hydrothermal fluids (HUBER et al., 2006). Incubation experiments of Guyamas Basin sediments indicate that anaerobic microbial methane oxidation is most active at $30-60^{\circ} \mathrm{C}$ (KALLMEYER and BoETIUS, 2004).

While the temperature range and isotopic composition of $9^{\circ} 50^{\prime} \mathrm{N}$ diffuse fluids are compatible with methane oxidation, other metabolic process that produce $\mathrm{CO}_{2}$, e.g. sulfate reduction coupled to oxidation of organic carbon other than methane (KNIEMEYER et al., 2007), cannot be discounted. The evidence presented here suggests that microbial methane oxidation may cycle methanogenic methane, and that further microbiological investigations of methanotrophy in diffuse fluids are warranted.

An evaluation of the potential for microbial modification of diffuse fluid composition can be made if fluid residence time of the diffuse fluid, quantity of biomass, and in-situ metabolic rate are known. At present the residence times of diffuse fluids are unknown, as are estimates of biomass and metabolic rates. As these data become available they will provide an important verification of the conclusions presented here.

\subsection{Numerical box model of microbial methane cycling}

The impact of microbial $\mathrm{CH}_{4}$ production and subsequent oxidation on the isotopic composition and concentration of $\mathrm{CH}_{4}$ and $\mathrm{CO}_{2}$ was modeled using a numerical-box model depicted in Figures 6 and 7. This model uses mass- and isotope-balance calculations to track carbon through the reservoirs of the box-model, and ignores kinetics, diffusion, and speciation. This model serves as a numerical method of providing a qualitative answer to the question: Are observed 
isotopic and concentration trends at Bio9/Bio9R and TWP/Y vents consistent with the microbial processes of methanogenesis coupled with methanotrophy?

The model is a spreadsheet-based series of iterative calculations of four different pools of carbon that are related through the processes of dilution, advection, methanogenesis and methanotrophy. Each carbon pool (geometric shapes in Figure 6) is represented in the model as a mass-isotope balance equation of the inputs and outputs to the pool, where each input or output (arrows in Figure 6) is expressed as a rate and an isotopic fractionation factor. As the goal of the model was to relate the observed $\delta^{13} \mathrm{C}$ values of $\mathrm{CH}_{4}$ and $\mathrm{CO}_{2}$ to the competing isotopic fractionations of microbial methanogenesis and methane oxidation, the model was tuned to reasonable initial conditions then run for $\sim 2500$ combinations of fractionations ( $\alpha$ - methanogenesis and $\left.\alpha \_A M O\right)$. The high-temperature pools of $\mathrm{CH}_{4}$ and $\mathrm{CO}_{2}$ are considered infinite reservoirs with concentrations and isotope values set to the average measured values, while the low-temperature pools are initially empty. Less well defined are the relative rates of methanogenesis (k_methanogenesis) and methane oxidation (k_AMO), dilution of the hightemperature fluid, and venting of the diffuse fluid to the surrounding ocean. The rate of methanogenesis was constrained by assuming that methanogenesis in the diffuse fluid is limited by the concentration of $\mathrm{H}_{2}$ available from the high-temperature fluid, after dilution, and considering a $4 \mathrm{H}_{2}: 1 \mathrm{CH}_{4}$ stoichiometry for methanogenesis (ZINDER, 1993). Rates of anaerobic methane oxidation relative to methanogenesis have been observed to range from $1 \%$ in coastal sites to over $1000 \%$ in gas hydrate environments (ORCUTT et al., 2005). Thus, the rate of methane oxidation was adjusted to approximate the rate of methanogenesis in terms of absolute amount of carbon processed per time step, and tuned to yield reasonable concentrations of lowtemperature $\mathrm{CH}_{4}$. The transfer of high-temperature $\mathrm{CH}_{4}$ and $\mathrm{CO}_{2}$ to the low-temperature fluid 
was constrained based on temperature estimates of dilution, adjusted to account for conductive cooling. For example, a $30^{\circ} \mathrm{C}$ diffuse fluid represents a $300^{\circ} \mathrm{C}$ fluid diluted ten-fold, a dilution factor of 10. The rate at which low-temperature $\mathrm{CO}_{2}$ and $\mathrm{CH}_{4}$ are vented to the ocean (advection) was constrained by the model result for low-temperature $\mathrm{CO}_{2}$ concentration, and thus is primarily linked to the input of $\mathrm{CO}_{2}$. The modeled isotopic results are fairly insensitive to advection (as advection is increased from $5 \%$ to $50 \%, \delta^{13} \mathrm{C}$ values of $\mathrm{CH}_{4}$ change by $-1.5 \%$ and $\delta^{13} \mathrm{C}$ of $\mathrm{CO}_{2}$ changes by $+0.05 \%$, a $5 \%$ and $1 \%$ change, respectively). However, the concentrations of $\mathrm{CH}_{4}$ and $\mathrm{CO}_{2}$ are highly sensitive to advection, decreasing advection from $50 \%$ to $5 \%$ leads to a $500 \%$ increase in the amount of $\mathrm{CH}_{4}$ and an $800 \%$ gain in $\mathrm{CO}_{2}$. An advection rate of $10 \%$ resulted in modeled diffuse $\mathrm{CH}_{4}$ and $\mathrm{CO}_{2}$ concentrations most similar to those measured at Bio9R and $\mathrm{Y}$ vents. Although this advection rate is suggestive of short residence times for the diffuse fluid, this value should be considered an artifact of the mass-balance approach rather than an observation-based constraint.

The model, initialized with values given in Table 3 and iterated until steady state was achieved, was run for thousands of combinations of methanogenic and anaerobic methane oxidation fractionation factors ( $\alpha \_$methanogenesis and $\alpha \_$AMO) to determine the best fit of measured isotope data from Bio9/Bio9R and TWP/Y vents (Table 4). The model accurately replicates the isotopic composition and steady-state concentrations of $\mathrm{CH}_{4}$ and $\mathrm{CO}_{2}$ at $\mathrm{Y}$ vent when fractionations for methanogenesis and methane oxidation are 1.035 and 1.008, respectively. The fractionations predicted by the box model for TWP/Y vent are within the $1.023 \leq \alpha \leq 1.064$ range of values for methanogenesis, as reported by Valentine et al. (2004), and within the $1.007 \leq \alpha \leq 1.012$ range reported for anaerobic methane oxidation in sediments (AlPERIN et al., 1988; MARTENS et al., 1999; WhitiCAR and FABER, 1986). 
The low $\mathrm{H}_{2}$ and $\mathrm{CH}_{4}$ concentrations at Bio9/Bio9R relative to TWP/Y suggest that less $\mathrm{CH}_{4}$ is cycled through Bio9R than $\mathrm{Y}$ vent. The diminished throughput of $\mathrm{CH}_{4}$ at Bio9R requires increased isotopic fractionations in order to fit the observed $\mathrm{CH}_{4}$ and $\mathrm{CO}_{2}$ isotopic data. Best-fit results suggest that a methanogenic fractionation of 1.071 and a $\mathrm{CH}_{4}$ oxidation fractionation of 1.053 to accommodate the low throughput of $\mathrm{CH}_{4}$. The increased methanogenic fractionation predicted at Bio9R is at the high end of experimental values (VALENTINE et al., 2004). Valentine et al. (2004) report increased values for methanogenic fractionation under $\mathrm{H}_{2}$-limiting conditions, a result that is consistent with the low $\mathrm{H}_{2}$ concentrations at Bio9 relative to TWP. Although model predicted $\mathrm{CH}_{4}$ oxidation isotopic fractionation at Bio9R is greater than fractionations observed for anaerobic $\mathrm{CH}_{4}$ oxidation in sediments (ALPERIN et al., 1988; MARTENS et al., 1999), the predicted values are within the range for aerobic $\mathrm{CH}_{4}$ oxidation (BARKER and FRITZ, 1981; COLEMAN et al., 1981). However, justifying an aerobic environment is difficult considering active methanogenesis necessitates the absence of oxygen. One possibility, albeit speculative, is that aerobic microenvironments could be more likely to occur in the less reducing fluids of Bio9/Bio9R (lower $\mathrm{H}_{2}$ concentrations than TWP/Y), yielding the increased isotopic fractionations associated with aerobic methanotrophy.

In summary, a box model that accounts for a flux of $\mathrm{CO}_{2}$ and $\mathrm{CH}_{4}$ from the hightemperature vent coupled with microbial $\mathrm{CO}_{2}$ reduction and $\mathrm{CH}_{4}$ oxidation in the lowtemperature vent, is consistent with the observed isotope and concentration data.

\section{CONCLUSIONS}

The vent sites located near $9^{\circ} 50^{\prime} \mathrm{N}$ along the EPR were the subject of close investigation by the AdVenture cruise series during the 1990's and a comprehensive set of volatile samples was 
collected. We report stable carbon isotope values for $\mathrm{CH}_{4}$ and $\mathrm{CO}_{2}$ from two vent pairs, both consisting of a high-temperature vent situated directly next to a low-temperature vent. The vent pairs are assumed to have the same source, and thus insight can be gained from the compositional and isotopic differences.

Examination of the isotopic differences between low-temperature fluids and their modified high-temperature suggests that microbial methanogenesis is active in $9^{\circ} 50^{\prime} \mathrm{N}$ diffuse fluids, perhaps coupled with methane oxidation. The diffuse fluids from $\mathrm{Y}$ and Bio9R are, on average, $10 \%$ lower in $\delta^{13} \mathrm{C}$ of $\mathrm{CH}_{4}$ and $0.55 \%$ lower in $\delta^{13} \mathrm{C}$ of $\mathrm{CO}_{2}$ than the source fluid measured at TWP and Bio9 vents. Microbial methanogenesis is consistent with diffuse fluid $\mathrm{CH}_{4}$ depeted in ${ }^{13} \mathrm{C}$ relative to the high-temperature source. Methanotrophy, a process yet to be identified in hydrothermal fluids, is consistent with diffuse fluid $\mathrm{CO}_{2}$ depeted in ${ }^{13} \mathrm{C}$ relative to the high-temperature source; although so are other $\mathrm{CO}_{2}$ producing metabolic reactions, such as microbial sulfate reduction. A numerical box model confirms that the competing processes of microbial methanogenesis and methane oxidation can result in the isotopic compositions and concentrations observed at $9^{\circ} 50^{\prime} \mathrm{N}$.

The -31 to $-26 \%$ o $\delta^{13} \mathrm{C}$ values of microbially cylced $\mathrm{CH}_{4}$ reported here are enriched in ${ }^{13} \mathrm{C}$ relative to the $<-50 \%$ values typically ascribed to "biogenic methane" (CICERONE and OREMLAND, 1988; SCHOELL, 1980; SCHOELL, 1988; WhitiCAR, 1990). Recent evidence showing methanogenic fractionation factors as low as 1.022 (VALENTINE et al., 2004), and evidence reported here suggesting the potential for microbial methane oxidation to enrich the methane pool in ${ }^{13} \mathrm{C}$, should serve as strong caveats when attempting to define the source of a natural methane sample according to its carbon isotope composition. The continued integration of 
molecular and genetic work, experimental culture studies and geochemical analysis will yield less equivocal interpretations of complex natural systems such as diffuse fluids.

This dataset demonstrates that microbial activity in diffuse fluids modifies the fluid geochemistry systematically, and detectably. As such, similar isotopic investigations may prove useful in the detection and assessment of methanogenic activity during future exploration.

Acknowledgements. The authors are grateful for the professionalism and abilities of the captains and crew of the R/V Atlantis II, the R/V Atlantis, and the DSV Alvin. This work was supported by NSF grants from the division of Ocean Science's MG\&G and RIDGE programs. The authors thank Karen Von Damm for providing the Mg and Si. The comments by Associate Editor Juske Horita and two anonymous greatly improved the manuscript. The manuscript also benefited from helpful discussions with Jeff Seewald and Stefan Sievert. 


\section{REFERENCES}

Alperin, M. J., Reeburgh, W. S., Whiticar, M. J., and Oremland, R. S., 1988. Carbon and hydrogen isotope fractionation resulting from anaerobic methane oxidation. In: McCarthy, J. J. (Ed.), Global Biogeochemical Cycles. American Geophysical Union, Washington.

Alt, J. C., 1995. Subseafloor processes in mid-ocean ridge hydrothermal systems. In: Humphris, S. E., Zierenberg, R. A., Mullineaux, L. S., and Thomson, R. E. Eds.), Seafloor hydrothermal systems; physical, chemical, biological, and geological interactions. American Geophysical Union, Washington, DC, United States.

Alt, J. C. and Teagle, D. A. H., 1999. The uptake of carbon during alteration of ocean crust. Geochimica et Cosmochimica Acta 63, 1527-1535.

Andresen, B., Barth, T., and Irwin, H., 1993. Yields and carbon isotopic composition of pyrolysis products from artificial maturation processes. Chemical Geology 106, 103-119.

Baker, E. T., Massoth, G. J., Walker, S. L., and Embley, R. W., 1993. A method for quantitatively estimating diffuse and discrete hydrothermal discharge. Earth and Planetary Science Letters 118, 235-249.

Barker, J. F. and Fritz, P., 1981. Carbon isotope fractionation during microbial methane oxidation. Nature 293, 289-291.

Baross, J. A., Wilcock, W. S. D., Kelley Deborah, S., Delong, E. F., and Cary, C. S., 2004. The Subsurface Biosphere at Mid-Ocean Ridges: Issues and Challenges. In: Wilcock, W. S. D., Delong, E. F., Kelley, D. S., Baross, J. A., and Cary, C. S. Eds.), The Subseafloor Biosphere at Mid-Ocean Ridges. Washington, DC, Washington, DC. 
Boetius, A., Ravenschlag, K., Schubert, C. J., Rickert, D., Widdel, F., Gieseke, A., Amann, R., Jorgensen, B. B., Witte, U., and Pfannkuche, O., 2000. A marine microbial consortium apparently mediating anaerobic oxidation of methane. Nature 407, 623-626.

Bottinga, Y. and Javoy, M., 1989. MORB degassing; evolution of $\mathrm{CO}_{2}$. Earth and Planetary Science Letters 95, 215-225.

Brand, W. A., 1996. High Precision Isotope Ratio Monitoring Techniques in Mass Spectrometry. Journal of Mass Spectrometry 31, 225-235.

Brazelton, W. J., Schrenk, M. O., Kelley, D. S., and Baross, J. A., 2006. Methane- and sulfurmetabolizing microbial communities dominate the Lost City hydrothermal field ecosystem. Applied and Environmental Microbiology 72, 6257-6270.

Butterfield, D. A., Jonasson, I. R., Massoth, G. J., Feely, R. A., Roe, K. K., Embley, R. E., Holden, J. F., McDuff, R. E., Lilley, M. D., and Delaney, J. R., 1999. Seafloor eruptions and evolution of hydrothermal fluid chemistry. In: Cann, J. R., Elderfield, H., and Laughton, A. Eds.), Mid-ocean ridges; dynamics of processes associated with creation of new ocean crust. Cambridge University Press, Cambridge, United Kingdom.

Butterfield, D. A. and Massoth, G. J., 1994. Geochemistry of North Cleft Segment vent fluids; temporal changes in chlorinity and their possible relation to recent volcanism. Journal of Geophysical Research, B, Solid Earth and Planets 99, 4951-4968.

Butterfield, D. A., Massoth, G. J., McDuff, R. E., Lupton, J. E., and Lilley, M. D., 1990. Geochemistry of hydrothermal fluids from Axial Seamount Hydrothermal Emissions Study vent field, Juan de Fuca Ridge; subseafloor boiling and subsequent fluid-rock interaction. In: Johnson, H. P. and Embley, R. W. Eds.), Special section; Axial Seamount; 
an active ridge axis volcano on the central Juan de Fuca Ridge. American Geophysical Union, Washington, DC, United States.

Butterfield, D. A., McDuff, R. E., Mottl, M. J., Lilley, M. D., Lupton, J. E., and Massoth, G. J., 1994. Gradients in the composition of hydrothermal fluids from the Endeavour Segment vent field; phase separation and brine loss. Journal of Geophysical Research, B, Solid Earth and Planets 99, 9561-9583.

Butterfield, D. A., Roe, K. K., Lilley, M. D., Huber, J. A., Baross, J. A., Embley Robert, W., and Massoth, G. J., 2004. Mixing, Reaction and Microbial Activity in the Sub-seafloor Revealed by Temporal and Spatial Variation in Diffuse Flow Vents at Axial Volcano. In: Wilcock, W. S. D., Delong, E. F., Kelley, D. S., Baross, J. A., and Cary, C. S. Eds.), The Subseafloor Biosphere at Mid-Ocean Ridges. American Geophysical Union, Washington, DC.

Campbell, B. J., Engel, A. S., Porter, M. L., and Takai, K., 2006. The versatile E-proteobacteria: Key players in sulfidic habitats. Nature Reviews Microbiology 4, 458-468.

Carbotte, S. M. and Macdonald, K. C., 1992. East Pacific Rise $8^{\circ}-10^{\circ} 30^{\prime} \mathrm{N}$; evolution of ridge segments and discontinuities from SeaMarc II and three-dimensional magnetic studies. Journal of Geophysical Research 97, 6959-6982.

Charlou, J. L., Donval, J. P., Douville, E., Jean, B. P., Radford, K. J., Fouquet, Y., Dapoigny, A., and Stievenard, M., 2000. Compared geochemical signatures and the evolution of Menez Gwen $\left(37^{\circ} 50^{\prime} \mathrm{N}\right)$ and Lucky Strike $\left(37^{\circ} 17^{\prime} \mathrm{N}\right)$ hydrothermal fluids, south of the Azores triple junction on the Mid-Atlantic Ridge. Chemical Geology 171, 49-75. 
Charlou, J. L., Donval, J. P., Fouquet, Y., Jean, B. P., and Holm, N., 2002. Geochemistry of high $\mathrm{H}_{2}$ and $\mathrm{CH}_{4}$ vent fluids issuing from ultramafic rocks at the Rainbow hydrothermal field (36²'N, MAR). Chemical Geology 191, 345-359.

Charlou, J. L., Donval, J. P., Jean, B. P., Dapoigny, A., and Rona, P. A., 1996. Gases and helium isotopes in high temperature solutions sampled before and after ODP Leg 158 drilling at TAG hydrothermal field (26 N, MAR). In: Rona, P. A. and Von Herzen, R. P. Eds.), Special section on Measurements and monitoring at the TAG hydrothermal field, MidAtlantic Ridge 26 degrees N, 45 degrees W. American Geophysical Union, Washington, DC, United States.

Chung, H. M. and Sackett, W. M., 1979. Use of stable carbon isotope compositions of pyrolytically derived methane as maturity indices for carbonaceous materials. Geochimica et Cosmochimica Acta 43, 1979-1988.

Cicerone, R. J. and Oremland, R. S., 1988. Biogeochemical aspects of atmospheric methane. In: Oremland, R. S. (Ed.), Special section on Methane biogeochemistry. American Geophysical Union, Washington, DC, United States.

Coleman, D. D., Risatti, J. B., and Schoell, M., 1981. Fractionation of carbon and hydrogen isotopes by methane-oxidizing bacteria. Geochimica et Cosmochimica Acta 45, 10331037.

Cooper, M. J., Elderfield, H., and Schultz, A., 2000. Diffuse hydrothermal fluids from Lucky Strike hydrothermal vent field; evidence for a shallow conductively heated system. Journal of Geophysical Research, B, Solid Earth and Planets 105, 19,369-19,375. 
Corliss, J. B., Dymond, J., Gordon, L. I., Edmond, J. M., Von, H. R. P., Ballard, R. D., Green, K., Williams, D., Bainbridge, A., Crane, K., and Van, A. T. H., 1979. Submarine thermal springs on the Galapagos Rift. Science 203, 1073-1083.

Cowen, J. P., Fornari, D., Shank, T. M., Love, B., Glazer, B., Treusch, A., Holmes, R. C., Soule, A., Baker, E. T., Tolstoy, M., and Pomranig, K. R., 2007. Volcanic Eruptions at East Pacific Rise Near $9^{\circ} 50^{\prime}$ N. EOS, Transactions, $A G U$ 88(7), 81.

Cowen, J. P., Wen, X., and Popp, B. N., 2002. Methane in aging hydrothermal plumes. Geochimica et Cosmochimica Acta 66, 3563-3571.

de Angelis, M. A., Lilley, M. D., Olson, E. J., and Baross, J. A., 1993. Methane oxidation in deep-sea hydrothermal plumes of the Endeavour Segment of the Juan de Fuca Ridge. Deep-Sea Research. Part I: Oceanographic Research Papers 40, 1169-1186.

Deming, J. W. and Baross, J. A., 1993. Deep-sea smokers; windows to a subsurface biosphere? In: Macko, S. A., Engel, M. H., and Shock, E. L. Eds.), Survivability of organic matter at high temperatures; implications for life. Pergamon, Oxford, International.

Detrick, R. S., Buhl, P., Vera, E. E., Mutter, J. C., Orcutt, J. A., Madsen, J. A., and Brocher, T. M., 1987. Multi-channel seismic imaging of a crustal magma chamber along the East Pacific Rise. Nature 326, 35-41.

Elderfield, H. and Schultz, A., 1996. Mid-ocean ridge hydrothermal fluxes and the chemical composition of the ocean. Annual Review of Earth and Planetary Sciences 24, 191-224.

Elsaied, H. E., Hayashi, T., and Naganuma, T., 2005. Molecular analysis of deep-sea hydrothermal vent aerobic methanotrophs by targeting genes of $16 \mathrm{~S}$ rRNA and particulate methane monooxygenase. Marine biotechnology 6, 503-509. 
Evans, W. C., White, L. D., and Rapp, J. B., 1988. Geochemistry of some gases in hydrothermal fluids from the southern Juan de Fuca Ridge. Journal of Geophysical Research, B, Solid Earth and Planets 93, 15,305-15,313.

Fey, A., Claus, P., and Conrad, R., 2004. Temporal change of ${ }^{13} \mathrm{C}$-isotope signatures and methanogenic pathways in rice field soil incubated anoxically at different temperatures. Geochimica et Cosmochimica Acta 68, 293-306.

Fornari, D., Tivey, M., Schouten, H., Perfit, M. R., Yoerger, D. R., Bradley, A., Edwards, M., Haymon, R., Scheirer, D., Von Damm, K. L., Shank, T., and Soule, A., 2004. Submarine Lava Flow Emplacement at the East Pacific Rise $9^{\circ} 50^{\prime} \mathrm{N}$ : Implications for Uppermost Ocean Crust Stratigraphy and Hydrothermal Fluid Circulation. In: German, C. R., Lin, J., and Parson, L. M. Eds.), Mid-Ocean Ridges: Hydrothermal Interactions Between the Lithosphere and Oceans. American Geophysical Union, Washington, DC.

Fornari, D. J., Shank, T., Von, D. K. L., Gregg, T. K. P., Lilley, M., Levai, G., Bray, A., Haymon, R. M., Perfit, M. R., and Lutz, R., 1998. Time-series temperature measurements at high-temperature hydrothermal vents, East Pacific Rise $9^{\circ} 49^{\prime}-51 ' \mathrm{~N}$; evidence for monitoring a crustal cracking event. Earth and Planetary Science Letters 160, 419-431.

Gillis, K. M. and Roberts, M. D., 1999. Cracking at the magma-hydrothermal transition; evidence from the Troodos Ophiolite, Cyprus. Earth and Planetary Science Letters 169, 227-244.

Girguis, P. R., Orphan, V.J., Hallam, S.J., and DeLong, E.F., 2003. Growth and Methane Oxidation Rates of Anaerobic Methanotrophic Archaea in a Continuous-Flow Bioreactor. Appl. Envir. Microbiol. 69, 5472-5482. 
Hansell, D. A. and Carlson, C. A., 1998. Deep-ocean gradients in the concentration of dissolved organic carbon. Nature 395, 263-266.

Haymon, R. M., Fornari, D. J., Von, D. K. L., Lilley, M. D., Perfit, M. R., Edmond, J. M., Shanks, W. C., III, Lutz, R. A., Grebmeier, J. M., Carbotte, S., Wright, D., McLaughlin, E., Smith, M., Beedle, N., and Olson, E., 1993. Volcanic eruption of the mid-ocean ridge along the East Pacific Rise crest at $9^{\circ} 45-52 ' \mathrm{~N}$; direct submersible observations of seafloor phenomena associated with an eruption event in April, 1991. Earth and Planetary Science Letters 119, 85-101.

Hinrichs, K. U., Summons, R. E., Orphan, V., Sylva, S. P., and Hayes, J. M., 2000. Molecular and isotopic analysis of anaerobic methane-oxidizing communities in marine sediments. In: Yalcin, M. N., Inan, S., Derenne, S., Farrimond, P., Freeman, K. H., Littke, R., Maxwell, J. R., Requejo, A. G., and Wilhelms, A. Eds.), Advances in organic geochemistry 1999; proceedings of the 19th international meeting on Organic geochemistry. Pergamon. Oxford-New York, International. 2000.

Holden, J. F., Summit, M., and Baross, J. A., 1998. Thermophilic and hyperthermophilic microorganisms in $3-30^{\circ} \mathrm{C}$ hydrothermal fluids following a deep-sea volcanic eruption. FEMS Microbiology Ecology 25, 33-41.

Horita, J., 2001. Carbon isotope exchange in the system $\mathrm{CO}_{2}-\mathrm{CH}_{4}$ at elevated temperatures. Geochimica et Cosmochimica Acta 65, 1907-1919.

Huber, J. A., Butterfield, D. A., and Baross, J. A., 2002. Temporal Changes in Archaeal Diversity and Chemistry in a Mid-Ocean Ridge Subseafloor Habitat. Appl. Environ. Microbiol. 68, 1585-1594. 
Huber, J. A., Butterfield, D. A., and Baross, J. A., 2003. Bacterial diversity in a subseafloor habitat following a deep-sea volcanic eruption. FEMS Microbiol Lett 43.

Huber, J. A., Butterfield, D. A., and Baross, J. A., 2006. Diversity and distribution of subseafloor Thermococcales populations in diffuse hydrothermal vents at an active deep-sea volcano in the northeast Pacific Ocean. Journal of Geophysical Research-Biogeosciences 111.

Hunt, J. M., 1996. Petroleum Geochemistry and Geology. W.H. Freeman and Company, New York.

James, R. H., Elderfield, H., and Palmer, M. R., 1995. The chemistry of hydrothermal fluids from the Broken Spur site, $29^{\circ} \mathrm{N}$ Mid-Atlantic Ridge. Geochimica et Cosmochimica Acta 59, 651-659.

Jannasch, H. W., 1995. Microbial interactions with hydrothermal fluids. In: Humphris, S. E., Zierenberg, R. A., Mullineaux, L. S., and Thomson, R. E. Eds.), Seafloor hydrothermal systems; physical, chemical, biological, and geological interactions. American Geophysical Union, Washington, DC, United States.

Javoy, M. and Pineau, F., 1991. The volatiles record of a 'popping' rock from the Mid-Atlantic Ridge at $14^{\circ} \mathrm{N}$ : chemical and isotopic composition of gas trapped in the vesicles. Earth and Planetary Science Letters 107, 598-611.

Javoy, M., Pineau, F., and Iiyama, I., 1978. Experimental determination of the isotopic fractionation between gaseous $\mathrm{CO}_{2}$ and carbon dissolved in tholeiitic magma; a preliminary study. Contributions to Mineralogy and Petrology 67, 35-39.

Jean-Baptiste, P., Charlou, J. L., Stievenard, M., Donval, J. P., Bougault, H., and Mevel, C., 1991. Helium and methane measurements in hydrothermal fluids from the Mid-Atlantic Ridge; the Snake Pit site at $23^{\circ}$ N. Earth and Planetary Science Letters 106, 17-28. 
Jeanthon, C., L'Haridon, S., Pradel, N., and Prieur, D., 1999. Rapid identification of hyperthermophilic methanococci isolated from deep-sea hydrothermal vents. International Journal of Systematic Bacteriology 49, 591-594.

Jeanthon, C., L'Haridon, S., Reysenbach, A. L., Vernet, M., Messner, P., Sleytr, U. B., and Prieur, D., 1998. Methanococcus infernos sp. nov., a novel hyperthermophilic lithotrophic methanogen isolated from a deep-sea hydrothermal vent. International Journal of Systematic Bacteriology 48, 913-919.

Johnson, K. S., Childress, J. J., Hessler, R. R., Sakamoto, A. C. M., and Beehler, C. L., 1988. Chemical and biological interactions in the Rose Garden hydrothermal vent field, Galapagos spreading center. In: Childress, J. J. (Ed.), Hydrothermal vents; a case study of the biology and chemistry of a deep-sea hydrothermal vent of the Galapagos Rift. Pergamon, Oxford-New York, International.

Jones, W. J., Leigh, J. A., Mayer, F., Woese, C. R., and Wolfe, R. S., 1983. MethanococcusJannaschii New-Species an Extremely Thermophilic Methanogen from a Submarine Hydro Thermal Vent. Archives of Microbiology 136, 254-261.

Jones, W. J., Stugard, C. E., and Jannasch, H. W., 1989. Comparison of Thermophilic Methanogens from Submarine Hydrothermal Vents. Archives of Microbiology 151, 314318.

Kallmeyer, J. and Boetius, A., 2004. Effects of Temperature and Pressure on Sulfate Reduction and Anaerobic Oxidation of Methane in Hydrothermal Sediments of Guaymas Basin. Appl. Environ. Microbiol. 70, 1231-1233.

Kashefi, K. and Lovley, D. R., 2003. Extending the Upper Temperature Limit for Life. Science 301, 934. 
Kelley, D. S. and Früh-Green, G. L., 1999. Abiogenic methane in deep-seated mid-ocean ridge environments; insights from stable isotope analyses. Journal of Geophysical Research, B, Solid Earth and Planets 104, 10,439-10,460.

Kelley, D. S. and Früh-Green, G. L., 2000. Volatiles in mid-ocean ridge environments. In: Dilek, Y., Moores, E. M., Elthon, D., and Nicolas, A. Eds.), Ophiolites and oceanic crust; new insights from field studies and the Ocean Drilling Program. Geological Society of America Boulder, CO.

Kelley, D. S. and Früh-Green, G. L., 2001. Volatile lines of descent in submarine plutonic environments: Insights from stable isotope and fluid inclusion analyses. Geochimica et Cosmochimica Acta 65, 3325-3346.

Kniemeyer, O., Musat, F., Sievert, S. M., Knittel, K., Wilkes, H., Blumenberg, M., Michaelis, W., Classen, A., Bolm, C., Joye, S. B., and Widdel, F., 2007. Anaerobic oxidation of short-chain hydrocarbons by marine sulphate-reducing bacteria. Nature 449, 898-901.

Lang, S. Q., Butterfield, D. A., Lilley, M. D., Paul Johnson, H., and Hedges, J. I., 2006.

Dissolved organic carbon in ridge-axis and ridge-flank hydrothermal systems. Geochimica et Cosmochimica Acta 70, 3830.

Lilley, M., Olson, E., and Lupton, J., 2006. Changes in Volatile Concentrations as a Result of the 2006 Eruption at $9^{\circ}$ N. EOS, Transactions, AGU 87(52), Abstract V13C-03.

Lilley, M. D., Baross, J. A., and Gordon, L. I., 1983. Reduced gases and bacteria in hydrothermal fluids; the Galapagos spreading center and $21^{\circ} \mathrm{N}$ East Pacific Rise. In: Rona, P. A., Bostroem, K., Laubier, L., and Smith, K. L., Jr. Eds.), Hydrothermal processes at seafloor spreading centers. Plenum Press, New York, NY, United States. 
Lilley, M. D., Butterfield, D. A., Lupton, J. E., and Olson, E. J., 2003. Magmatic events can produce rapid changes in hydrothermal vent chemistry. Nature 422, 878-81.

Lilley, M. D., Butterfield, D. A., Olson, E. J., Lupton, J. E., Macko, S. A., and McDuff, R. E., 1993. Anomalous $\mathrm{CH}_{4}$ and $\mathrm{NH}_{4}{ }^{+}$concentrations at an unsedimented mid-ocean-ridge hydrothermal system. Nature 364, 45-47.

Manning, C. E., Weston, P. E., and Mahon, K. I., 1996. Rapid high-temperature metamorphism of East Pacific Rise gabbros from Hess Deep. Earth and Planetary Science Letters 144, 123-132.

Martens, C. S., Albert, D. B., and Alperin, M. J., 1999. Stable isotope tracing of anaerobic methane oxidation in the gassy sediments of Eckernfoerde Bay, German Baltic Sea. American Journal of Science 299, 589-610.

Massoth, G. J., Milburn, H. B., Hammond, S. R., Butterfield, D. A., McDuff, R. E., and Lupton, J. E., 1988. The geochemistry of submarine venting fluids at Axial Volcano, Juan de Fuca Ridge: New sampling methods and a VENTS program rationale. In: DeLuca, M. P. and Babb, I. Eds.), Global Venting, Midwater, and Benthic Ecological Processes. Natl. Undersea Research Program, Silver Spring, MD.

Merlivat, L., Pineau, F., and Javoy, M., 1987. Hydrothermal vent waters at $13^{\circ} \mathrm{N}$ on the East Pacific Rise; isotopic composition and gas concentration. Earth and Planetary Science Letters 84, 100-108.

Michaelis, W., Seifert, R., Nauhaus, K., Treude, T., Thiel, V., Blumenberg, M., Knittel, K., Gieseke, A., Peterknecht, K., Pape, T., Boetius, A., Amann, R., Jorgensen, B. B., Widdel, F., Peckmann, J., Pimenov, N. V., and Gulin, M. B., 2002. Microbial reefs in the Black Sea fueled by anaerobic oxidation of methane. Science 297, 1013-5. 
Nercessian, O., Bienvenu, N. g., Moreira, D., Prieur, D., and Jeanthon, C., 2005. Diversity of functional genes of methanogens, methanotrophs and sulfate reducers in deep-sea hydrothermal environments. Environmental microbiology 7, 118-32.

Niemann, H., Losekann, T., de Beer, D., Elvert, M., Nadalig, T., Knittel, K., Amann, R., Sauter, E. J., Schluter, M., Klages, M., Foucher, J. P., and Boetius, A., 2006. Novel microbial communities of the Haakon Mosby mud volcano and their role as a methane sink. Nature 443, 854-858.

Orcutt, B., Boetius, A., Elvert, M., Samarkin, V., and Joye, S. B., 2005. Molecular biogeochemistry of sulfate reduction, methanogenesis and the anaerobic oxidation of methane at Gulf of Mexico cold seeps. Geochimica et Cosmochimica Acta 69, 42674281.

Orphan, V. J., House, C. H., Hinrichs, K.-U., McKeegan, K. D., and DeLong, E. F., 2001. Methane-Consuming Archaea Revealed by Directly Coupled Isotopic and Phylogenetic Analysis. Science 293, 484-487.

Pineau, F. and Javoy, M., 1983. Carbon isotopes and concentrations in mid-oceanic ridge basalts. Earth and Planetary Science Letters 62, 239-257.

Pineau, F. and Javoy, M., 1994. Strong degassing at ridge crests; the behaviour of dissolved carbon and water in basalt glasses at $14^{\circ} \mathrm{N}$, Mid-Atlantic Ridge. Earth and Planetary Science Letters 123, 179-198.

Pineau, F., Javoy, M., and Bottinga, Y., 1976. ${ }^{13} \mathrm{C} /{ }^{12} \mathrm{C}$ ratios of rocks and inclusions in popping rocks of the Mid-Atlantic Ridge and their bearing on the problem of isotopic composition of deep-seated carbon. Earth and Planetary Science Letters 29, 413-421. 
Proskurowski, G., Lilley, M. D., and Brown, T. A., 2004. Isotopic evidence of magmatism and seawater bicarbonate removal at the Endeavour hydrothermal system. Earth and Planetary Science Letters 225, 53-61.

Ravizza, G., Blusztajn, J., Von, D. K. L., Bray, A. M., Bach, W., and Hart, S. R., 2001. Sr isotope variations in vent fluids from $9^{\circ} 46^{\prime}-9^{\circ} 54^{\prime} \mathrm{N}$ East Pacific Rise; evidence of a nonzero-Mg fluid component. Geochimica et Cosmochimica Acta 65, 729-739.

Sackett, W. M., 1993. Carbon isotope exchange between methane and amorphous carbon at $700^{\circ} \mathrm{C}$. Organic Geochemistry 20, 43-45.

Sansone, F. J., Mottl, M. J., Olson, E. J., Wheat, C. G., and Lilley, M. D., 1998. CO2 -depleted fluids from mid-ocean ridge-flank hydrothermal springs. Geochimica et Cosmochimica Acta 62, 2247-2252.

Sarda, P. and Graham, D., 1990. Mid-ocean ridge popping rocks; implications for degassing at ridge crests. Earth and Planetary Science Letters 97, 268-289.

Schimmelmann, A., Sessions, A. L., and Mastalerz, M., 2006. Hydrogen Isotopic (D/H) Composition of Organic Matter During Diagenesis and Thermal Maturation. Annual Review of Earth and Planetary Sciences 34, 501-533.

Schoell, M., 1980. The hydrogen and carbon isotopic composition of methane from natural gases of various origins. Geochimica et Cosmochimica Acta 44, 649-662.

Schoell, M., 1988. Multiple origins of methane in the Earth. In: Schoell, M. (Ed.), Origins of methane in the Earth. Elsevier, Amsterdam, Netherlands.

Schrenk, M. O., Kelley, D. S., Delaney, J. R., and Baross, J. A., 2003. Incidence and diversity of microorganisms within the walls of an active deep-sea sulfide chimney. Appl Environ Microbiol 69, 3580-92. 
Schultz, A. and Elderfield, H., 1999. Controls on the physics and chemistry of seafloor hydrothermal circulation. In: Cann, J. R., Elderfield, H., and Laughton, A. Eds.), Midocean ridges; dynamics of processes associated with creation of new ocean crust. Cambridge University Press, Cambridge, United Kingdom.

Seewald, J. S., 2003. Organic-inorganic interactions in petroleum-producing sedimentary basins. Nature 426, 327-333.

Shank, T. M., Fornari, D. J., Von Damm, K. L., Lilley, M. D., Haymon, R. M., and Lutz, R. A., 1998. Temporal and spatial patterns of biological community devolpment at nascent deep-sea hydrothermal vents (950'N, East Pacific Rise). Deep-Sea Research II 45, 465515.

Shanks, W. C., III, Bohlke, J. K., and Seal, R. R., II, 1995. Stable isotopes in mid-ocean ridge hydrothermal systems; interactions between fluids, minerals, and organisms. In: Humphris, S. E., Zierenberg, R. A., Mullineaux, L. S., and Thomson, R. E. Eds.), Seafloor hydrothermal systems; physical, chemical, biological, and geological interactions. American Geophysical Union, Washington, DC, United States.

Simoneit, B. R. T., Goodfellow, W. D., and Franklin, J. M., 1992. Hydrothermal petroleum at the seafloor and organic matter alteration in sediments of Middle Valley, Northern Juan de Fuca Ridge. Applied Geochemistry 7, 257-264.

Summit, M. and Baross, J. A., 1998. Thermophilic subseafloor microorganisms from the 1996 North Gorda Ridge eruption. Deep-Sea Research II 45, 2751-2766.

Summit, M. and Baross, J. A., 2001. A novel microbial habitat in the mid-ocean ridge subsurface. Proc. Natl. Acad. Sci. 98, 2185-2163. 
Takai, K. and Horikoshi, K., 1999. Genetic diversity of archaea in deep-sea hydrothermal vent enivronments. Genetics 152, 1285-1297.

Taylor, B. E., 1986. Magmatic volatiles; isotopic variation of C, H, and S. In: Valley, J. W., Taylor, H. P., Jr., and O'Neil, J. R. Eds.), Stable isotopes in high temperature geological processes. Mineralogical Society of America, Washington, DC, United States.

Teske, A., Hinrichs, K.-U., Edgcomb, V., de-Vera-Gomez, A., Kysela, D., Sylva, S.-P., Sogin, M.-L., and Jannasch, H.-W., 2002. Microbial diversity of hydrothermal sediments in the Guaymas Basin: Evidence for anaerobic methanotrophic communities. Applied and Environmental Microbiology.

Valentine, D. L., Blanton, D. C., and Reeburgh, W. S., 2000. Hydrogen production by methanogens under low-hydrogen conditions. Archives of Microbiology 174, 415-421.

Valentine, D. L., Chidthaisong, A., Rice, A., Reeburgh, W. S., and Tyler, S. C., 2004. Carbon and hydrogen isotope fractionation by moderately thermophilic methanogens. Geochimica et Cosmochimica Acta 68, 1571-1590.

Von Damm, K. L., 1995. Controls on the chemistry and temporal variability of seafloor hydrothermal fluids. In: Humphris, S. E., Zierenberg, R. A., Mullineaux, L. S., and Thomson, R. E. Eds.), Seafloor hydrothermal systems; physical, chemical, biological, and geological interactions. American Geophysical Union, Washington, DC, United States.

Von Damm, K. L., 2000. Chemistry of hydrothermal vent fluids from $9^{\circ}-10^{\circ} \mathrm{N}$, East Pacific Rise; "time zero," the immediate posteruptive period. Journal of Geophysical Research, B, Solid Earth and Planets 105, 11203-11222. 
Von Damm, K. L., 2004. Evolution of the Hydrothermal System at East Pacific Rise 950'N:

Geochemical Evidence for Changes in the Upper Oceanic Crust. In: German, C. R., Lin, J., and Parson, L. Eds.), Mid-Ocean Ridges Hydrothermal Interactions Between the Lithosphere and Oceans. American Geophysical Union, Washington, DC.

Von Damm, K. L., Bates, M. J., Carmichael, S. K., Meana-Prado, F., and McDermott, J. M., 2006. Response of the 9-10N EPR Hydrothermal Systems to Recent Volcanic Eruptions. EOS, Transactions, AGU 87(52), Abstract V13C-02.

Von Damm, K. L., Edmond, J. M., Measures, C. I., and Grant, B., 1985. Chemistry of submarine hydrothermal solutions at Guaymas Basin, Gulf of California. Geochimica et Cosmochimica Acta 49, 2221-2237.

Von Damm, K. L. and Lilley, M. D., 2004. Diffuse Flow Hydrothermal Fluids from 9.50' N East Pacific Rise: Origin, Evolution and Biogeochemical Controls. In: Wilcock, W. S. D., Delong, E. F., Kelley, D. S., Baross, J. A., and Cary, C. S. Eds.), The Subseafloor Biosphere at Mid-Ocean Ridges. American Geophysical Union, Washington, DC.

Von Damm, K. L., Oosting, S. E., Kozlowski, R., Buttermore, L. G., Colodner, D. C., Edmonds, H. N., Edmond, J. M., and Grebmeier, J. M., 1995. Evolution of East Pacific Rise hydrothermal vent fluids following a volcanic eruption. Nature 375, 47-50.

Welhan, J. A. and Craig, H., 1979. Methane and hydrogen in East Pacific Rise hydrothermal fluids. Eos, Transactions, American Geophysical Union 60, 863.

Welhan, J. A. and Craig, H., 1983. Methane, hydrogen and helium in hydrothermal fluids at $21^{\circ} \mathrm{N}$ on the East Pacific Rise. In: Rona, P. A., Bostroem, K., Laubier, L., and Smith, K. L., Jr. Eds.), Hydrothermal processes at seafloor spreading centers. Plenum Press, New York, NY, United States. 
Welhan, J. A. and Lupton, J. E., 1987. Light hydrocarbon gases in Guaymas Basin hydrothermal fluids; thermogenic versus abiogenic origin. AAPG Bulletin 71, 215-223.

Whiticar, M. J., 1990. A geochemical perspective of natural gas and atmospheric methane. In: Durand, B. and Behar, F. Eds.), Advances in organic geochemistry 1989; Part I, Organic geochemistry in petroleum exploration. Pergamon, Oxford-New York, International.

Whiticar, M. J. and Faber, E., 1986. Methane oxidation in sediment and water column environments; isotope evidence. In: Leythaeuser, D. and Rullkoetter, J. Eds.), Advances in organic geochemistry 1985; Part II, Molecular and general organic geochemistry. Pergamon, Oxford-New York, International.

Whitman, W. B., Bowen, T. L., and Taylor, D. R., 1992. The Methanogenic Bacteria. In: Balows, A., Trüper, H. G., Dworkin, M., Harder, W., and Schleifer, K.-H. Eds.), The Prokaryotes Second Edition. Springer-Verlag, New York.

Zinder, S. H., 1993. Physiological ecology of methanogens. In: Ferry, J. G. (Ed.), Methanogenesis: Ecology, Physiology, Biochemistry, and Genetics. Chapman and Hall, New York. 
Table 1. Comparison of measured hydrothermal fluids, see Table 2 for calculated endmember values. As no correction is applied to the measured $\delta^{13} \mathrm{C}$ values of $\mathrm{CH}_{4}$, that data is presented in Table 2 as an endmember value.

\begin{tabular}{|c|c|c|c|c|c|c|c|c|c|}
\hline Vent & Year & $\mathbf{T}^{\circ} \mathbf{C}$ & $\begin{array}{c}{[\mathrm{Mg}]} \\
\mathrm{mmol} / \mathrm{kg} \\
\text { measured }\end{array}$ & $\begin{array}{c}{[\mathrm{Si}] \mathrm{mmol} / \mathrm{kg}} \\
\text { measured }\end{array}$ & $\begin{array}{c}\text { Si] } \mathbf{m m o l} / \mathbf{k g} \\
\text { end- } \\
\text { member }\end{array}$ & $\begin{array}{c}{\left[\mathrm{H}_{2}\right]} \\
\mathrm{mmol} / \mathrm{kg} \\
\text { measured }\end{array}$ & $\begin{array}{c}{\left[\mathrm{CH}_{4}\right]} \\
\mathrm{mmol} / \mathrm{kg} \\
\mathrm{measured}\end{array}$ & $\begin{array}{c}{\left[\mathrm{CO}_{2}\right]} \\
\mathrm{mmol} / \mathrm{kg} \\
\text { measured }\end{array}$ & $\underset{\text { measured }}{\delta^{13} \mathrm{CO}_{2}}$ \\
\hline Bio9R & 1994 & 30 & 51.9 & 0.8 & $13.2^{\mathrm{a}}$ & 0.001 & 0.006 & 9.5 & -4.18 \\
\hline Bio9R & 1995 & 33 & 48.5 & 1.2 & $14.8^{\mathrm{a}}$ & 0.002 & 0.004 & 9.2 & -3.42 \\
\hline Bio9R & 1997 & 27 & 51.6 & 0.7 & $13.0^{\mathrm{a}}$ & 0.001 & 0.003 & 4.3 & -2.62 \\
\hline Bio9 & 1991 & 368 & 25.2 & 5.1 & 9.9 & 1.448 & 0.082 & 24.2 & -3.70 \\
\hline Bio9 & 1992 & 388 & 5.7 & 6.5 & 7.0 & 1.258 & 0.043 & 119.3 & -4.01 \\
\hline Bio9 & 1994 & 359 & 2.1 & 11.9 & $13.2^{\mathrm{a}}$ & 0.313 & 0.088 & 180.3 & -4.02 \\
\hline Bio9 & 1995 & 364 & 2.2 & 14.2 & $14.8^{\mathrm{a}}$ & 0.328 & 0.081 & 128.1 & -4.05 \\
\hline Bio9 & 1997 & 369 & 2.3 & 12.6 & $13.0^{\mathrm{a}}$ & 0.201 & 0.087 & 109.5 & -3.95 \\
\hline $\mathrm{Y}$ & 1991 & 55 & 46.7 & 0.7 & $12.7^{\mathrm{b}}$ & 0.002 & 0.468 & 10.1 & -3.02 \\
\hline $\mathrm{Y}$ & 1992 & 22 & 51.4 & 0.7 & $12.7^{b}$ & 0.001 & 0.087 & 4.6 & -2.33 \\
\hline $\mathrm{Y}$ & 1994 & 20 & 50.6 & 0.7 & 12.8 & 0.007 & 0.016 & 5.0 & -2.64 \\
\hline $\mathrm{Y}$ & 1995 & 25 & 51.4 & 0.9 & $13.8^{\mathrm{c}}$ & 0.000 & 0.014 & 5.9 & -3.14 \\
\hline $\mathrm{Y}$ & 1997 & 18 & 51.9 & 0.5 & 18.1 & 0.001 & 0.004 & 3.8 & -2.16 \\
\hline TWP & 1994 & 358 & 26.9 & 6.3 & 12.8 & 4.049 & 0.060 & 53.4 & -4.14 \\
\hline TWP & 1995 & 341 & 36.0 & 4.6 & $13.8^{\mathrm{c}}$ & 1.592 & 0.033 & 33.2 & -4.17 \\
\hline TWP & 1997 & 307 & 2.7 & 17.2 & 18.1 & 3.245 & 0.093 & 73.1 & -4.17 \\
\hline $\mathrm{V}$ & 1991 & 70 & 43.6 & 2.8 & $7.6^{\mathrm{d}}$ & 0.030 & 0.540 & 6.8 & -2.42 \\
\hline Q & 1991 & 371 & 21.5 & $\mathrm{n} / \mathrm{a}$ & $\mathrm{n} / \mathrm{a}$ & 1.772 & 0.050 & 130.0 & -4.14 \\
\hline $\mathrm{A}$ & 1991 & 396 & 45.2 & 0.6 & $\mathrm{n} / \mathrm{a}$ & 3.630 & 0.020 & 8.8 & -1.86 \\
\hline
\end{tabular}

(a) endmember Si values reflect averages from multiple samples as reported in Von Damm (2004)

(b) endmember Si values reflect average of all $1994 \mathrm{Y}$ vent data, as no data exist for TWP (the neighboring high temperature vent) in 1991 and 1992

(c) endmember Si values reflect averages of Si and Mg data from multiple 1995 TWP samples

(d) as V vent has no proximal high-temperature vent the endmember Si value reflects an average of all 1991 endmember Si values reported by Von Damm (2004) 
Table 2. Comparison of endmember hydrothermal fluids. Endmember values correct the measured concentration data of high temperature vents for seawater entrained during sampling by normalizing data to a zero $\mathrm{Mg}$ value. Further corrections are applied to low temperature concentration data so that the proximal high-temperature vent data can be directly compared. Low temperature concentration data are normalized to the endmember $\mathrm{Si}$ value of the neighboring high temperature vent (presented in this table as $\mathrm{Si}$ endmember). $\mathrm{CO}_{2}$ isotope data is corrected for all samples for entrained seawater, using a mass-isotope balance approach and assuming the endmember vent fluid has a zero $\mathrm{Mg}$ concentration.

\begin{tabular}{|c|c|c|c|c|c|c|c|c|c|c|}
\hline Sample & Vent & Year & $\mathbf{T}^{\circ} \mathbf{C}$ & $\begin{array}{c}\text { Measured } \\
{[\mathrm{Mg}]} \\
\mathrm{mmol} / \mathrm{kg}\end{array}$ & $\begin{array}{c}\text { Measured } \\
{[\mathrm{Si}]} \\
\mathrm{mmol} / \mathrm{kg}\end{array}$ & $\begin{array}{c}\text { Endmember } \\
{\left[\mathrm{H}_{2}\right]^{\mathrm{a}, \mathrm{b}}} \\
\mathrm{mmol} / \mathrm{kg}\end{array}$ & $\begin{array}{c}\text { Endmember } \\
{\left[\mathrm{CH}_{4}\right]^{\mathrm{a}, \mathrm{b}}} \\
\mathrm{mmol} / \mathrm{kg}\end{array}$ & $\begin{array}{c}\text { Endmember } \\
{\left[\mathrm{CO}_{2}\right]^{\mathrm{a}, \mathrm{b}}} \\
\mathrm{mmol} / \mathrm{kg}\end{array}$ & $\begin{array}{c}\delta^{13} \mathbf{C} \\
\mathrm{CH}_{4}{ }^{\mathrm{c}} \\
\% 0\end{array}$ & $\begin{array}{c}\delta^{13} \mathbf{C} \\
\mathbf{C O}_{2}{ }^{\mathrm{d}, \mathrm{e}} \\
\% 0\end{array}$ \\
\hline $2752-2$ & Bio9R & 1994 & 30 & 51.91 & 0.8 & 0.02 & 0.12 & 188.35 & -26.8 & -5.36 \\
\hline $3025-3$ & Bio9R & 1995 & 33 & 48.48 & 1.2 & 0.03 & 0.06 & 134.36 & -25.2 & -4.31 \\
\hline $3154-10$ & Bio9R & 1997 & 27 & 51.60 & 0.7 & 0.02 & 0.06 & 104.66 & -26.2 & -5.03 \\
\hline $2351-3$ & Bio9 & 1991 & 368 & 25.24 & 5.1 & 2.80 & 0.16 & 44.76 & -34.6 & -3.86 \\
\hline $2498-3$ & Bio9 & 1992 & 388 & 5.73 & 6.5 & 1.41 & 0.05 & 133.76 & -19.6 & -4.02 \\
\hline $2735-4$ & Bio9 & 1994 & 359 & 2.07 & 11.9 & 0.33 & 0.09 & 187.66 & -19.4 & -4.02 \\
\hline $3030-2$ & Bio9 & 1995 & 364 & 2.21 & 14.2 & 0.34 & 0.09 & 133.70 & -19.0 & -4.06 \\
\hline $3157-9$ & Bio9 & 1997 & 369 & 2.31 & 12.6 & 0.21 & 0.09 & 114.44 & -18.9 & -3.95 \\
\hline $2372-3$ & $\mathrm{Y}$ & 1991 & 55 & 46.71 & 0.7 & 0.04 & 10.20 & 220.02 & -31.5 & -3.68 \\
\hline $2499-2$ & Y & 1992 & 22 & 51.41 & 0.7 & 0.03 & 1.87 & 98.11 & -27.5 & -4.17 \\
\hline $2852-7$ & Y & 1994 & 20 & 50.55 & 0.7 & 0.16 & 0.38 & 121.16 & -33.8 & -4.42 \\
\hline $3020-3$ & $\mathrm{Y}$ & 1995 & 24.7 & 51.35 & 0.9 & 0.01 & 0.28 & 115.56 & -32.6 & -4.81 \\
\hline $3158-10$ & $\mathrm{Y}$ & 1997 & 18.2 & 51.89 & 0.5 & 0.03 & 0.21 & 194.40 & -33.6 & -4.64 \\
\hline $2850-5$ & TWP & 1994 & 358 & 26.92 & 6.3 & 8.36 & 0.12 & 107.83 & -21.0 & -4.22 \\
\hline $3035-6$ & TWP & 1995 & 341 & 36.00 & 4.6 & 4.89 & 0.10 & 102.00 & -22.5 & -4.36 \\
\hline $3169-11$ & TWP & 1997 & 307 & 2.65 & 17.2 & 3.42 & 0.10 & 76.91 & -21.4 & -4.18 \\
\hline $2366-2$ & $\mathrm{~V}$ & 1991 & 70 & 43.56 & 2.8 & 0.09 & 1.52 & 19.28 & -34.8 & -3.80 \\
\hline $2368-3$ & Q & 1991 & 371 & 21.47 & n.m. & 3.01 & 0.08 & 219.25 & -19.9 & -4.16 \\
\hline $2755-7$ & Q & 1994 & 297 & 2.43 & n.m. & 0.51 & 0.12 & 168.78 & -16.83 & -3.83 \\
\hline $3176-11$ & Q & 1997 & 319 & 2.56 & n.m. & 0.27 & 0.13 & 153.75 & -18.96 & -3.70 \\
\hline $2366-4$ & A & 1991 & 396 & 45.20 & 0.6 & 27.07 & 0.14 & 51.07 & -26.5 & n.m. \\
\hline $3547-129$ & ${ }^{\circ} \mathrm{N}$ seawater ${ }^{\mathrm{f}}$ & 2001 & 2 & 52.0 & 0.155 & b.d.1. & b.d.l. & 2.3 & n.m. & -0.4 \\
\hline & SJdFR $^{g}$ & & 285 & & & 0.53 & 0.12 & 4.5 & -19.3 & -8.3 \\
\hline & $21^{\circ} \mathrm{NEPR}^{\mathrm{g}}$ & & 350 & & & 1.7 & 0.09 & 5.7 & -16.0 & -7.0 \\
\hline & $13^{\circ} \mathrm{NEPR}^{\mathrm{g}}$ & & 300 & & & 0.14 & 0.051 & 18.4 & -18.1 & -4.8 \\
\hline & MARK $^{\mathrm{g}}$ & & 350 & & & 0.48 & 0.06 & 6.7 & n.m. & n.m. \\
\hline & Ienez Gwen ${ }^{\mathrm{g}}$ & & 284 & & & 0.05 & 2.63 & 20 & -19.2 & -9.1 \\
\hline & Broken Spur ${ }^{\mathrm{g}}$ & & 360 & & & 1.03 & 0.13 & 7.1 & -18.5 & -9.0 \\
\hline
\end{tabular}

(a) High-temperature endmember concentrations determined by extrapolation to a zero-Mg value, see text for details, total cumulative error $\pm 3 \%$

(b) Low-temperature endmember concentrations determined by extrapolation to a zero-Mg adjusted Si value, see text for details, total cumulative error $\pm 5 \%$

(c) Average ${ }^{13} \mathrm{CH}_{4}$ measurement error $\pm 0.3 \%$

(d) Average ${ }^{13} \mathrm{CO}_{2}$ measurement error $\pm 0.05 \%$ 
(e) Measured ${ }^{13} \mathrm{CO}_{2}$ corrected to account for entrained seawater bicarbonate, average corrected ${ }^{13} \mathrm{CO}_{2}$ error $\pm 0.2 \%$, see text for details

(f) $9^{\circ} 50^{\prime} \mathrm{N}$ bottom seawater, sampling and handling identical to other samples

(g) $\operatorname{SJdF}\left(\right.$ Evans et al., 1988), $21^{\circ} \mathrm{N}$ EPR (Welhan and Craig, 1983), $13^{\circ} \mathrm{N}$ EPR (Merlivat et al., 1987), MARK

(Jean-Baptiste et al., 1991), Menez Gwen (Charlou et al., 2000), Broken Spur (James et al., 1995), concentrations are maximum reported, isotope values are median of range reported

n.m.: not measured

b.d.1.: beyond detection limits 
Table 3. Best fit results and boundary conditions of box model presented in Figure 6

\begin{tabular}{|c|c|c|c|c|}
\hline parameter & $\begin{array}{c}\text { model } \\
\text { Bio9/Bio9R }\end{array}$ & $\begin{array}{c}\text { average } \\
\text { Bio9/Bio9R }\end{array}$ & $\begin{array}{l}\text { model } \\
\text { TWP/Y }\end{array}$ & $\begin{array}{l}\text { average } \\
\text { TWP/Y }\end{array}$ \\
\hline k_methanogenesis ${ }^{\text {a,b }}$ & 0.0015 & & 0.0045 & \\
\hline $\mathbf{k}_{-} \mathbf{A M O}{ }^{\mathrm{c}}$ & 0.8 & & 0.6 & \\
\hline k_recycled ${ }^{\mathrm{d}}$ & 0.015 & & 0.045 & \\
\hline dilution of HiT fluid ${ }^{e}$ & 10 & & 10 & \\
\hline k_vent to ocean ${ }^{\mathrm{f}}$ & 0.10 & & 0.10 & \\
\hline$\delta^{13} \mathrm{CO}_{2 \_} \mathrm{HiT}(\%)$ & & -3.96 & & -4.3 \\
\hline$\delta^{13} \mathrm{CH}_{4}$ HiT (\%o) & & -19.3 & & -21.6 \\
\hline$\left[\mathrm{CO}_{2}\right]_{-} \mathrm{HiT}(\mathrm{mmol} / \mathrm{kg})$ & & 120 & & 95 \\
\hline$\left[\mathrm{CH}_{4}\right] \_\mathrm{HiT}(\mathrm{mmol} / \mathrm{kg})$ & & 0.10 & & 0.11 \\
\hline$\left[\mathrm{H}_{2}\right] \_\mathrm{HiT}(\mathrm{mmol} / \mathrm{kg})$ & & (1.19) & & $(5.63)$ \\
\hline$\delta^{13} \mathrm{CO}_{2 \_} \mathrm{LoT}(\%)$ & -4.87 & $-4.90 *$ & -4.73 & $-4.55 *$ \\
\hline$\delta^{13} \mathrm{CH}_{4 \_} \mathrm{LoT}(\%)$ & -26.05 & $-26.07 *$ & -31.90 & $-31.90 *$ \\
\hline$\alpha \_$methanogenesis ${ }^{g}$ & 1.071 & & 1.0373 & \\
\hline$\alpha \_A M O^{h}$ & 1.053 & & 1.0101 & \\
\hline$\left[\mathrm{CO}_{2}\right]_{-} L \mathrm{LoT}(\mathrm{mmol} / \mathrm{kg})$ & 81 & $(142)$ & 126 & (132) \\
\hline$\left[\mathrm{CH}_{4}\right]_{-} \mathrm{LoT}(\mathrm{mmol} / \mathrm{kg})$ & 0.24 & $(0.080)$ & 1.07 & $(0.68)$ \\
\hline
\end{tabular}

Boundary conditions are in bold, results in italics, data used for tuning of initial conditions in (parenthesis)

* Average measured isotope values of diffuse fluids were benchmark that determined the best fit of model results. Best fit determined by minimizing deviation of model isotope compositions from observed low-temperature isotope compositions (see Table 4).

(a) $\mathrm{k} \_$methanogenesis $=\left[\mathrm{CH}_{4}\right] \_$produced $/\left[\mathrm{CO}_{2}\right] \_\mathrm{HiT}$

(b) rate constrainted by maximum $\mathrm{CH}_{4}$ produced by drawdown of $\left[\mathrm{H}_{2}\right]$ according to a $4 \mathrm{H}_{2}: 1 \mathrm{CH}_{4}$ stoichiometry; e.g. if $1 \mathrm{mmol} / \mathrm{kg} \mathrm{H}$ consumed, $0.25 \mathrm{mmol} / \mathrm{kg} \mathrm{CH}_{4}$ is produced, and original $\mathrm{CO}_{2}$ is $142 \mathrm{mmol} / \mathrm{kg}$, then $\mathrm{k} \_$methanogenesis $=.25 / 142=.17$

(c) k_AMO constrained to yield lower oxidation rates (in terms of total amount carbon) than methanogenesis and tuned to model results for $\left[\mathrm{CH}_{4}\right]_{\_} \mathrm{LoT}$

(d) rate of recycling between pool of low-temperature $\mathrm{CO}_{2}$ and $\mathrm{CH}_{4}$, the methanogenic rate is 10x that of methane oxidation rate, and is set to k_methanogenesis (with no dilution)

(e) dilution factor approximated using temperature constraints and estimates of conductive cooling

(f) rate of loss to ocean constrained by model results for $\left[\mathrm{CO}_{2}\right] \_$LoT

(g) $\alpha \_$methanogenesis $=\mathrm{R} \_\mathrm{CO}_{2} / \mathrm{R}_{-} \mathrm{CH}_{4}$, as determined by best fit to boundary conditions, where $\mathrm{R}={ }^{13} \mathrm{C} /{ }^{12} \mathrm{C}$

(h) $\alpha \_A M O=R \_C H_{4} / R \_\mathrm{CO}_{2}$, as determined by best fit to boundary conditions 
Table 4. Best-fit model results for fractionation factors and isotopic composition selected from 2500 simulations using unique combinations of fractionation factors for methanogenesis and methane oxidation.

\begin{tabular}{|c|c|c|c|c|}
\hline \multicolumn{5}{|l|}{ Bio9/Bio9R } \\
\hline$\alpha \_$methanogenesis & $\alpha \_$AMO & $\delta^{13} \mathrm{CO}_{2-} \mathrm{L}$ & ${ }^{3} \mathrm{CH}_{4} \_\mathrm{L}$ & eviation ${ }^{\mathrm{a}}$ \\
\hline$\left(\mathrm{R}_{\mathrm{CO} 2} / \mathrm{R}_{\mathrm{CH} 4}\right)$ & $\left(\mathrm{R}_{\mathrm{CH} 4} / \mathrm{R}_{\mathrm{CO} 2}\right)$ & $(\% o)$ & $(\% o)$ & \\
\hline 1.071 & 1.053 & -4.87 & -26.05 & 0.03 \\
\hline 1.079 & 1.062 & -4.97 & -26.10 & 0.08 \\
\hline 1.072 & 1.054 & -4.89 & -26.18 & 0.11 \\
\hline
\end{tabular}

\section{TWP/Y}

$\alpha \_$methanogenesis $\alpha \_$AMO $\delta^{13} \mathrm{CO}_{2 \_}$LoT $\delta^{13} \mathrm{CH}_{4 \_ \text {LoT deviation }}{ }^{\mathrm{a}}$

$\begin{array}{ccccc}\left(\mathrm{R}_{\mathrm{CO} 2} / \mathrm{R}_{\mathrm{CH} 4}\right) & \left(\mathrm{R}_{\mathrm{CH} 4} / \mathrm{R}_{\mathrm{CO} 2}\right) & (\%) & (\% \circ) & \\ 1.035 & 1.008 & -4.73 & -31.87 & 0.18 \\ 1.040 & 1.013 & -4.82 & -31.96 & 0.27 \\ 1.036 & 1.009 & -4.75 & -32.09 & 0.28\end{array}$

(a) deviation calculated as square root of the total sum of squares between model result and measured isotope value (for $\mathrm{CH}_{4}$ and $\mathrm{CO}_{2}$ ) 
Figure 1. Bathymetry and vent locations of 950’N East Pacific Rise study. Courtesy of D. Fornari. 
Figure 2. Hydrogen concentration plotted on a log scale. The dramatic depletion in hydrogen at low-temperature vents is hypothesized to be the result of microbial consumption during methanogenesis (Von Damm and Lilley, 2004). 
Figure 3. Expected $\mathrm{CH}_{4}-\mathrm{CO}_{2}$ equilibrium isotopic fractionations from Horita (2001). Both high-temperature and low-temperature vents appear to be out of isotopic equilibrium (hightemperature vents measured at $300-370^{\circ} \mathrm{C}$ have isotopic signatures indicating equilibrium temperatures $420-585^{\circ} \mathrm{C}$, while the isotopic signature of diffuse fluids at $20-50^{\circ} \mathrm{C}$, indicate equilibrium temperatures of $240-375^{\circ} \mathrm{C}$ ). Note anomalous $\delta^{13} \mathrm{CH}_{4}$ value of $1991 \mathrm{Bio} 9386^{\circ} \mathrm{C}$ sample, where isotopic depletion is due to unique environmental conditions immediately following the 1991 seafloor eruption. 
Figure 4. Comparison of TWP and $\mathrm{Y}$ vents. Plots of a) $\mathrm{H}_{2}$ concentration, b) $\mathrm{CH}_{4}$ concentration, c) $\delta^{13} \mathrm{C}$ of $\mathrm{CO}_{2}$ and d) $\delta^{13} \mathrm{C}$ of $\mathrm{CH}_{4}$ from 1994,1995 , and 1997. Concentration data and $\delta^{13} \mathrm{C}$ values of $\mathrm{CH}_{4}$ are compatible with active methanogenesis at $\mathrm{Y}$ vent. The depletions in $\delta^{13} \mathrm{C}$ of $\mathrm{CO}_{2}$ at $\mathrm{Y}$ vent indicate microbial methane oxidation. 
Figure 5. Comparison of Bio9 and Bio9R vents. Plots of a) $\mathrm{H}_{2}$ concentration, b) $\mathrm{CH}_{4}$ concentration, c) $\delta^{13} \mathrm{C}$ of $\mathrm{CO}_{2}$ and d) $\delta^{13} \mathrm{C}_{\text {of }} \mathrm{CH}_{4}$ from 1994, 1995, and 1997. Consumption of hydrogen, and the depletion in $\delta^{13} \mathrm{C}_{\text {of }} \mathrm{CH}_{4}$ at the low-temperature Bio9R vent is compatible with methanogenesis. The depletions in $\delta^{13} \mathrm{C}$ of $\mathrm{CO}_{2}$ at Bio9R vent indicate microbial methane oxidation. The combined effect of microbial methanogenesis and methane oxidation may account for the apparent increase in 1994 and decrease in 1995 and 1997 in $\mathrm{CH}_{4}$ concentrations. 
Figure 6. Numerical box model describing active microbial methane cycling in low-temperature diffuse fluids. All arrows are associated with a rate and the indicated fluxes are associated with an isotopic fractionation factor corresponding to the microbiological process. Rates were estimated according to relative concentrations, and included dilution effects (seawater mixing with high-temperature fluids). Rates, fractionation factors, boundary conditions and results are shown in Table 3. 
Figure 7. Plot of $\delta^{13} \mathrm{C}_{\text {of }} \mathrm{CH}_{4}$ vs $\delta^{13} \mathrm{C}$ of $\mathrm{CO}_{2}$ simplifying the result of a numerical box model run (final composition) as the sum of its principle components- methanogenesis, methanotrophy, and mixing. Arrows indicate microbial processes, dashed lines indicate mixing of microbial product with reservoir of carbon. Because of high concentrations of $\mathrm{CO}_{2}$ input from high-temperature fluids, the final $\delta^{13} \mathrm{C}$ value of $\mathrm{CO}_{2}$ is only slightly depleted in ${ }^{13} \mathrm{C}(\sim 0.55 \%)$ relative to the initial value, despite the production of $\mathrm{CO}_{2}$ highly depleted in ${ }^{13} \mathrm{C}$. Note that methanogenesis causes the initial pool of $\mathrm{CO}_{2}$ to be slightly enriched in ${ }^{13} \mathrm{C}_{\text {as }} \mathrm{CH}_{4}$ depleted in ${ }^{13} \mathrm{C}$ is produced. 


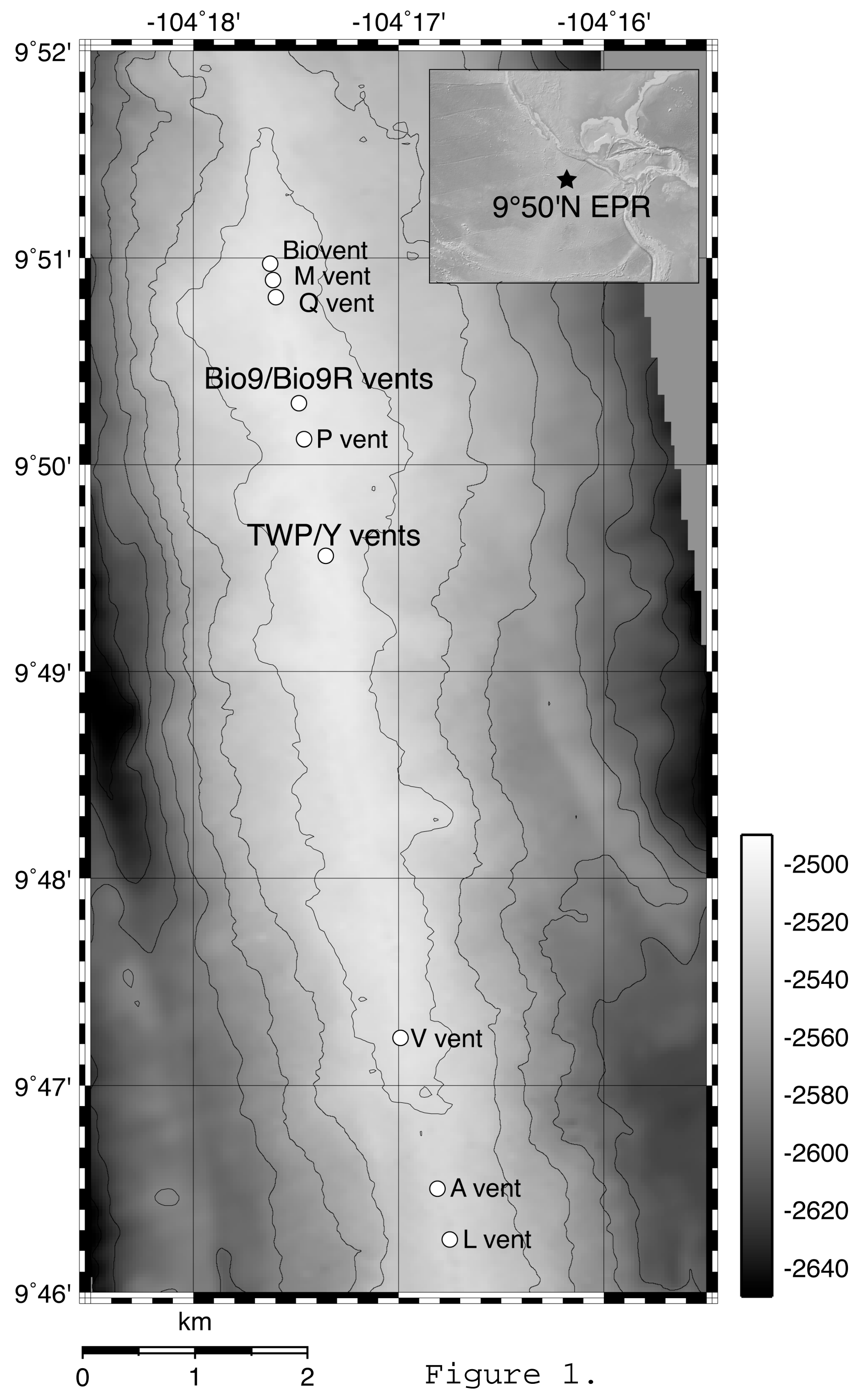




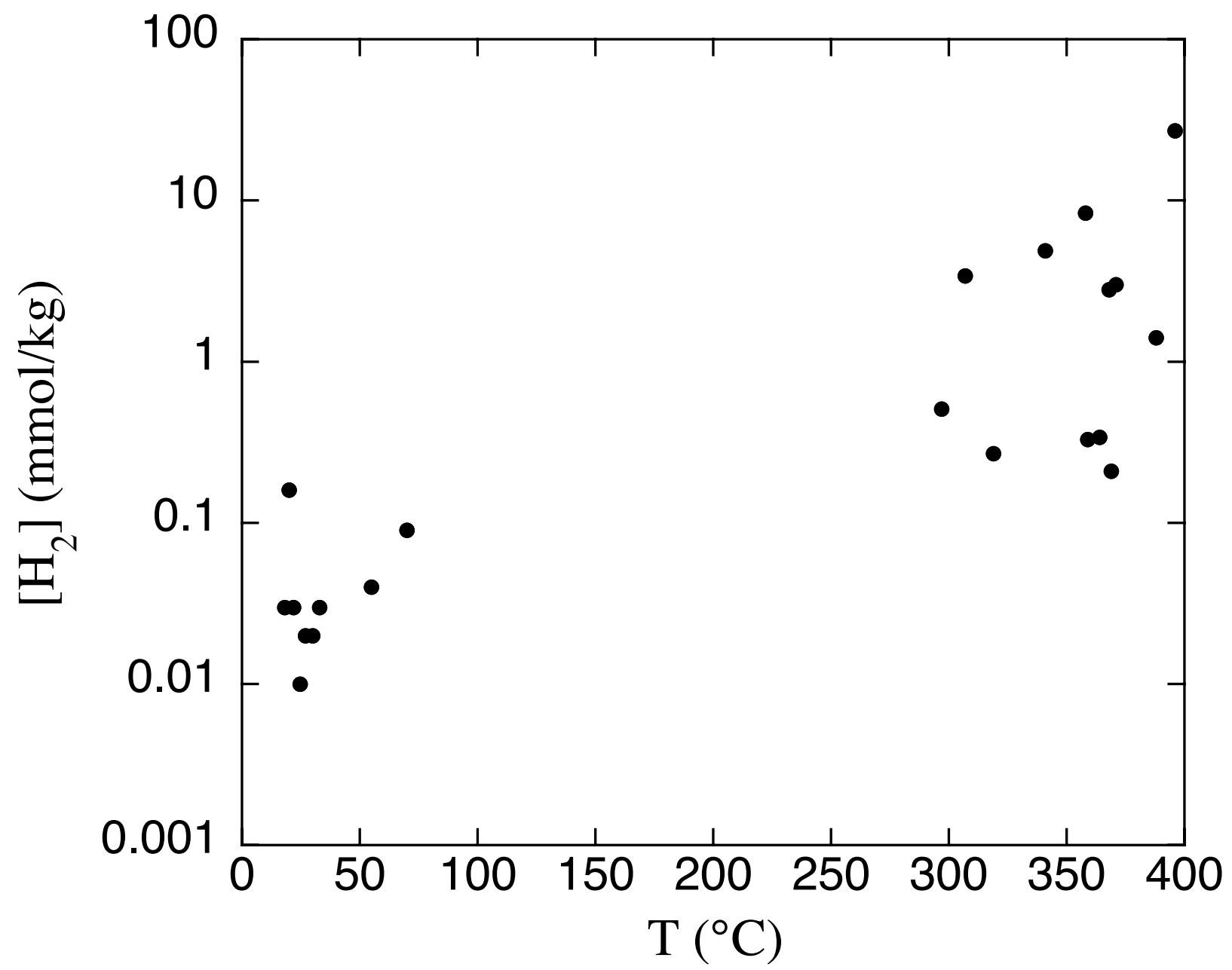

Figure 2 . 


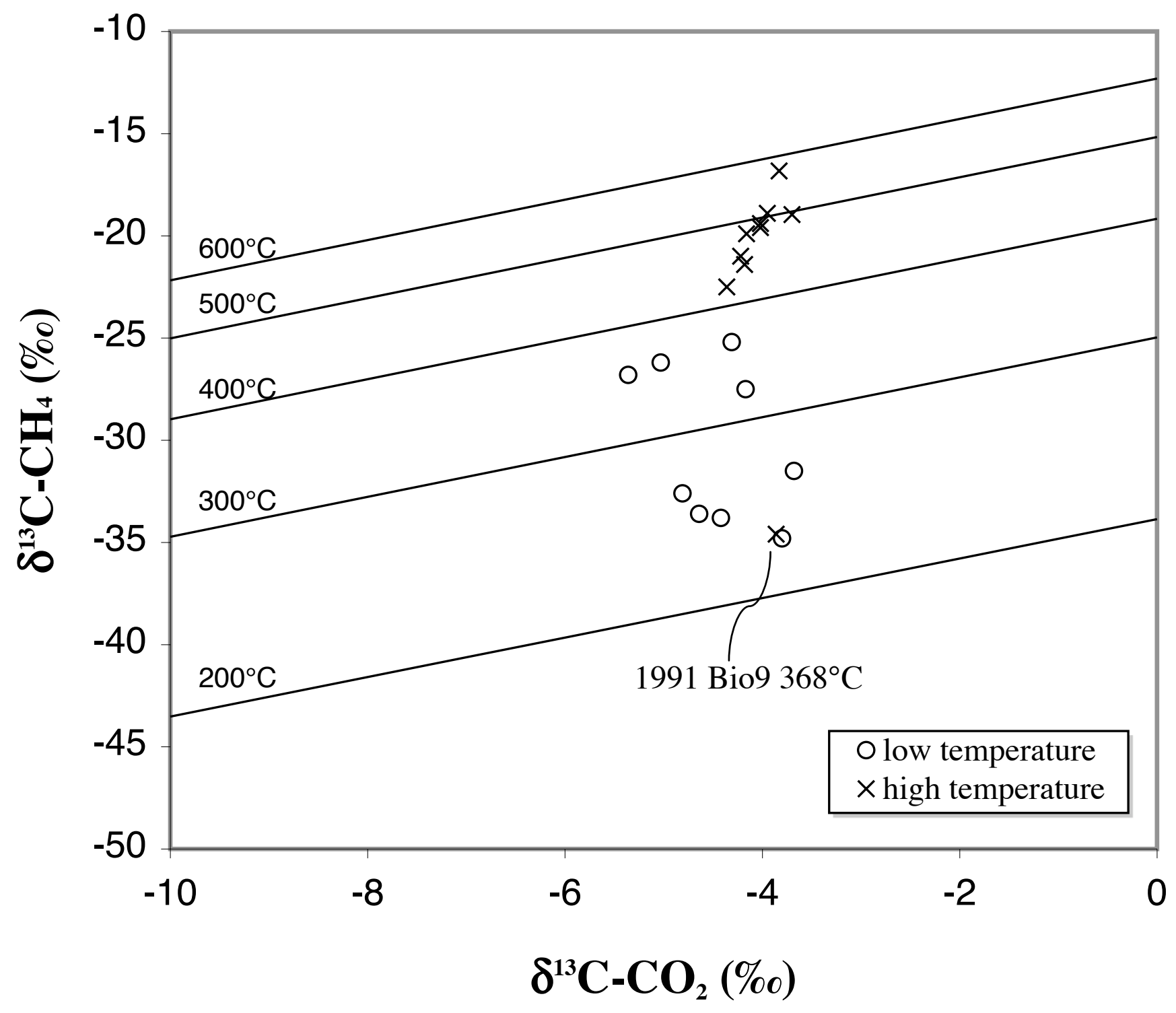

Figure 3. 


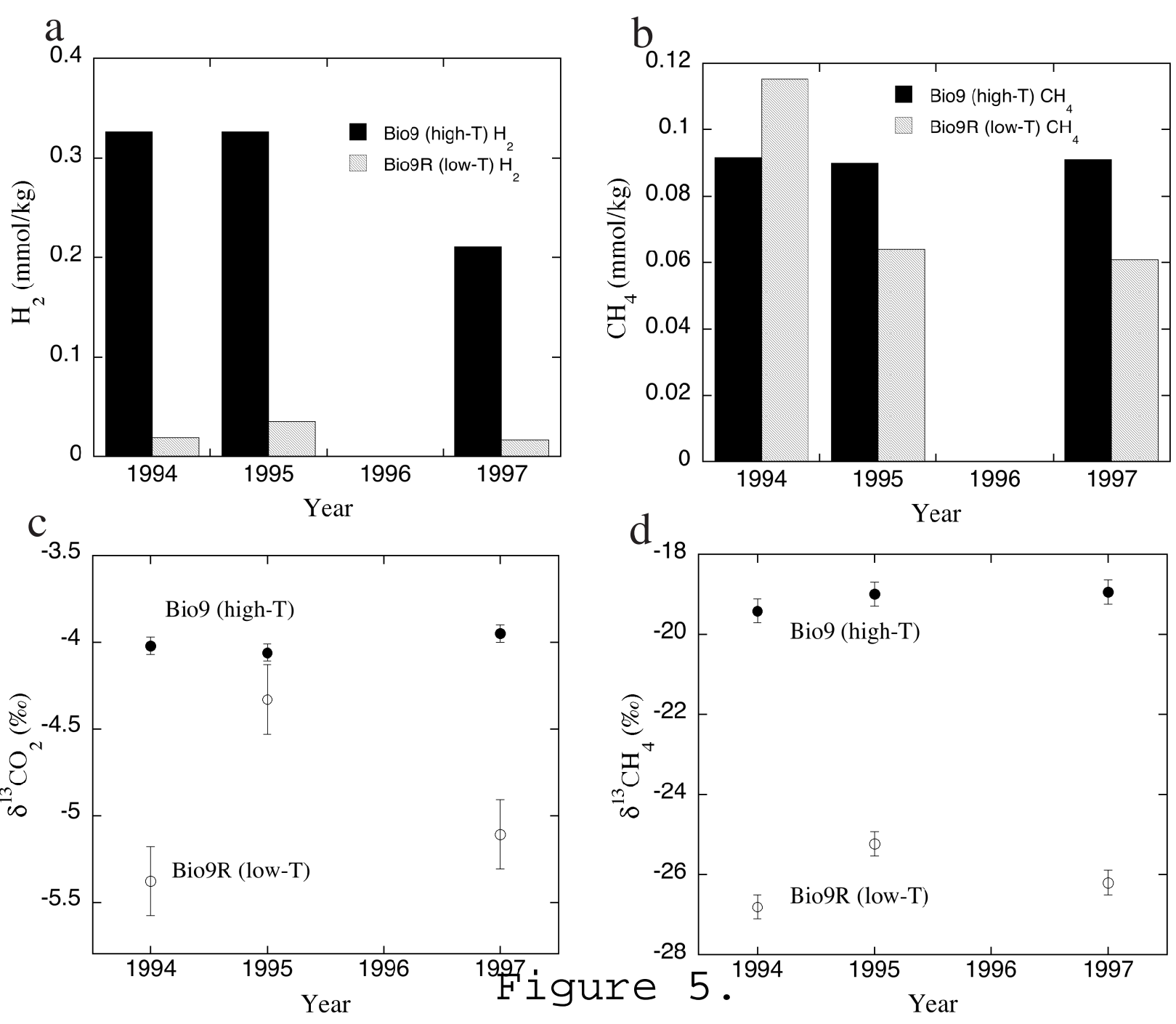




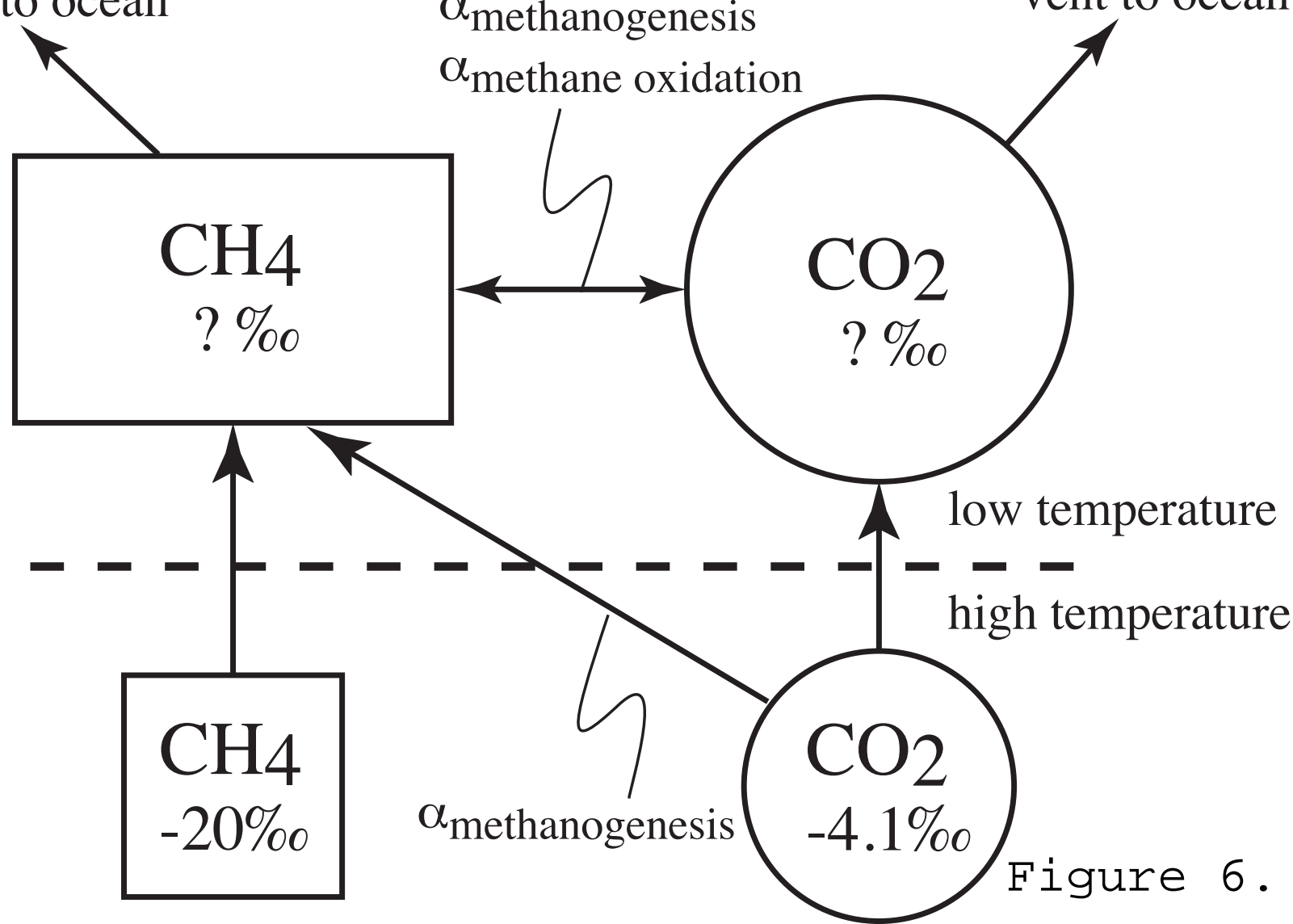




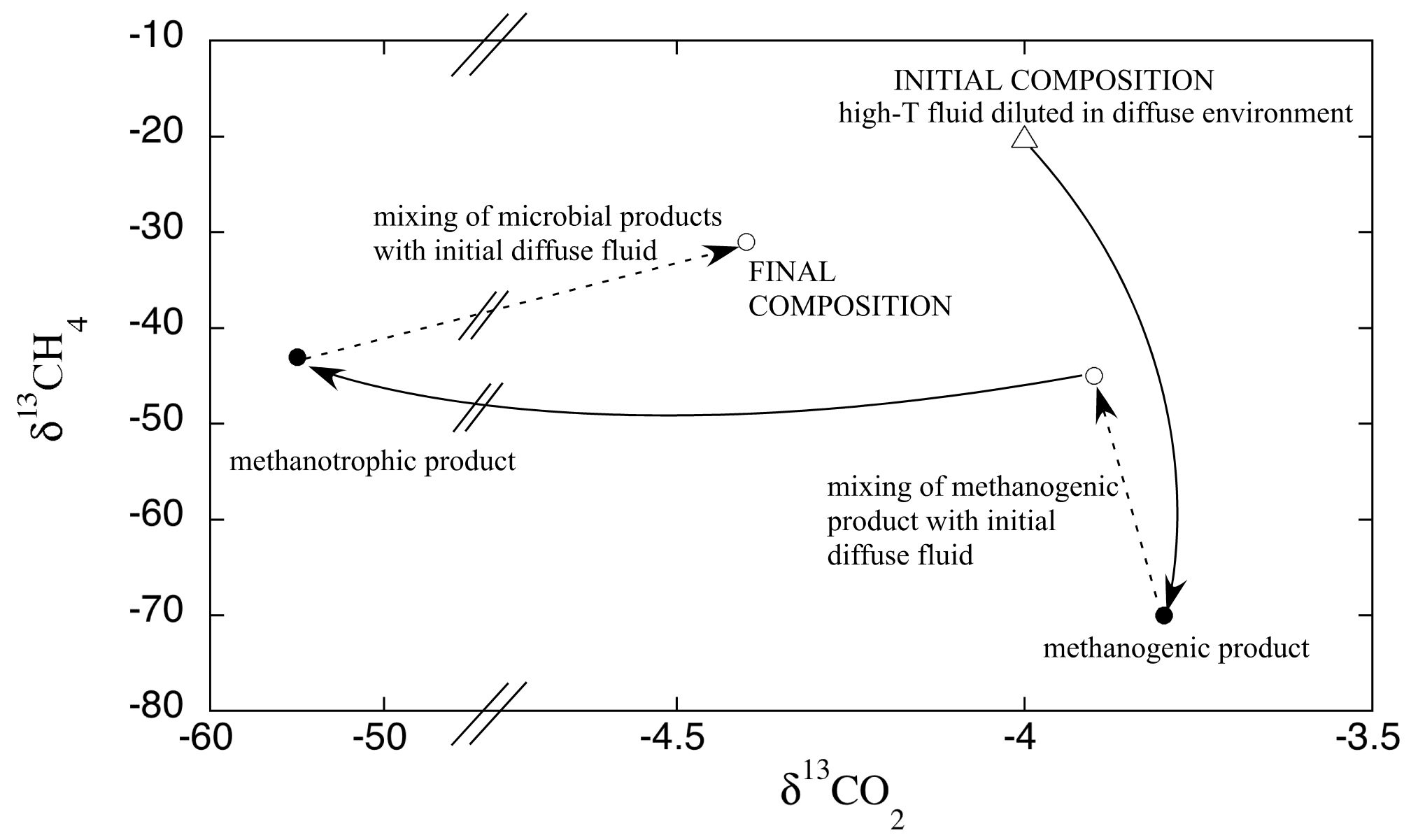

Figure 7 . 